
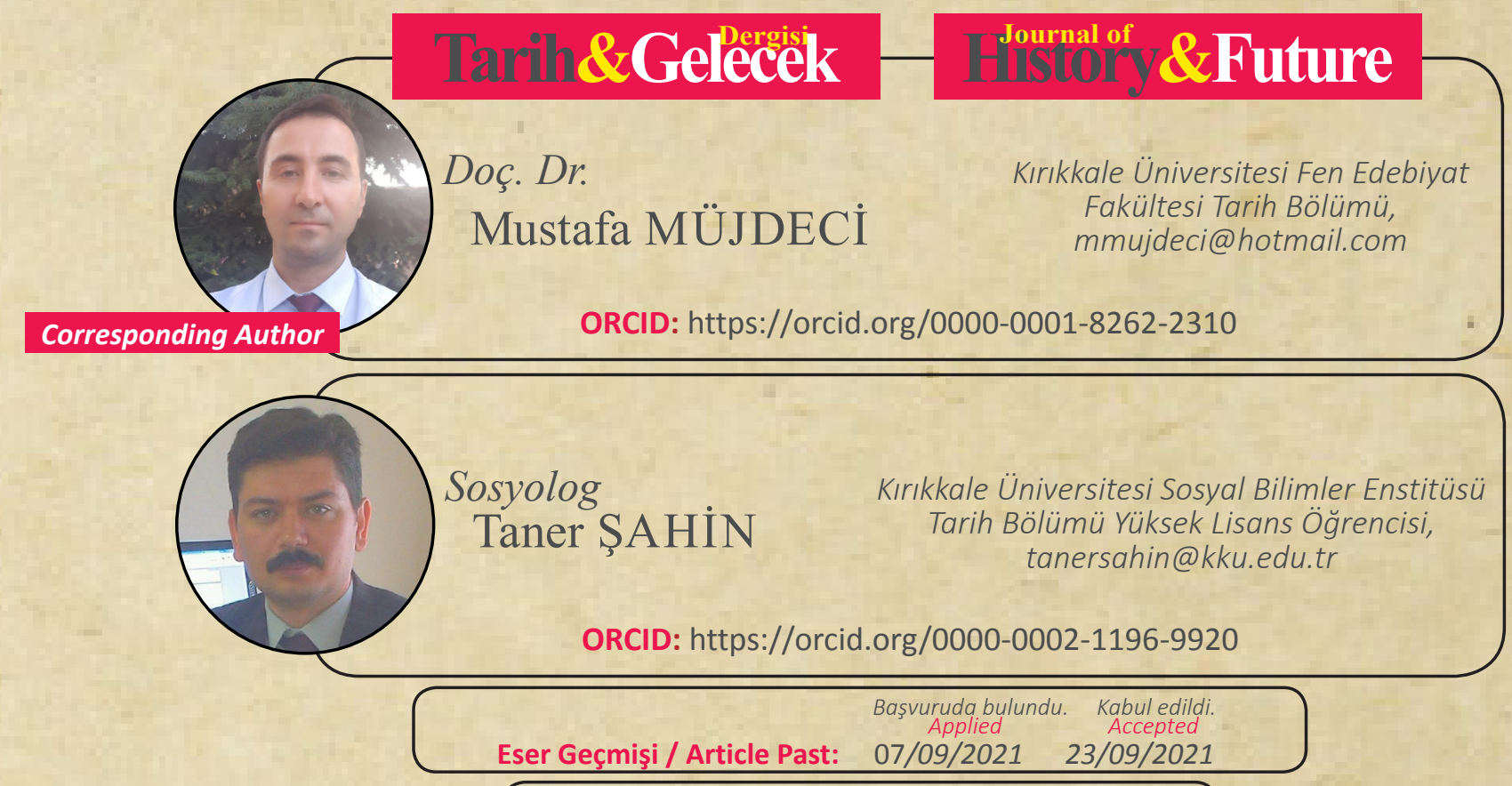

Indexed by ERA OPJENACCES

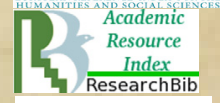

RII $\mathbf{S} \mathbf{A}$
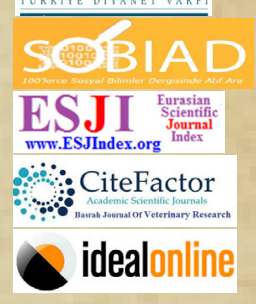

Araştırma Makalesi

DOI: http://dx.doi.org/10.21551/jhf.992550

Research Paper

Orjinal Makale / Orginal Paper

\title{
Milliyetçi ve İlmî Kültür Dergiciliğinin Bir Örneği: Türklük Dergisi
}

\author{
An Example of Nationalist and Scientific Cultural Journalism: \\ Turkluk Journal
}

\begin{abstract}
$\ddot{O} z$
$\mathrm{Bu}$ makalede Nisan 1939'da yayınlanmaya başlayan ve Kasım 1940'a kadar yayın hayatını sürdüren Türklük dergisi konu edilmiştir. Türkiye'de milliyetçiliğin yükselişte olduğu bir dönemde - II. Dünya Savaşı'nın hemen öncesinde- İsmail Hami Danişmend tarafından çıkarılan Türklük, aynı dönemde çıkarılan Ergenekon, Bozkurt ve Gök-Börü dergileri gibi Türk kültürü ve milliyetçiliği konularında makalelere yer vermiştir. Türklük, savaş dönemindeki pek çok derginin aksine propaganda dergiciliğinden ziyade Türk kültürünün maddi ve manevi unsurlarını ele almıştır.

“Milliyetçi Kültür Mecmuası” olarak bilinen Türklük, 15 sayı yayınlanmıştır. Millet, milliyet, kültür ve ırk meselelerine fazlaca yer verilen Türklük, daha ilk sayısında İsmail Hami Danişmend tarafindan "milliyetçi olduğundan dolayı 1rkçı, dilci, kültürcü ve vatancı" olarak nitelendirilmiştir. Milliyetçi, ilmî araştırma ve kültür dergisi olan Türklük'te o dönemin çok tartışılan konularının başında gelen irk ve milliyet kavramları üzerinde değerlendirmeler dikkat çekmiştir. Bu çalışmada Türklük dergisi şekil ve içerik açısından incelenmiş, Türk fikir hayatındaki yeri ve önemine dair tespitlerde bulunulmuştur.
\end{abstract}

Anahtar kelimeler: Türklük, İsmail Hami Danişmend, İkinci Dünya Savaşı, Milliyetçilik, Irkçılık 


\begin{abstract}
In this article, Turkluk magazine, which started to be published in April 1939 and continued its publication life until November 1940, has been the subject. At a time when nationalism was on the rise in Turkey - just before the Second World War - Turkluk, published by İsmail Hami Danişmend, included articles on Turkish culture and nationalism such as Ergenekon, Bozkurt and Gok-Boru magazines published in the same period. Unlike many magazines during the war period, Turkluk dealt with the material and spiritual elements of Turkish culture rather than propaganda journalism.

Turkluk, known as the "Nationalist Culture Magazine", has been published in 15 issues. Turkluk, in which the nation, nationality, culture and race issues are heavily covered, was described as "racist, linguistic, culturalist and patriotic" by İsmail Hami Danishmend in its very first issue. In Turkluk, which is a nationalist, scientific research and culture magazine, evaluations on the concepts of race and nationality, which were among the most discussed issues of that period, attracted attention. In this study, Turkluk magazine was examined in terms of form and content, and determinations were made about its place and importance in Turkish intellectual life.
\end{abstract}

Keywords: Turkluk, Ismail Hami Danismend, Second World War, Nationalism, Racism

\title{
Giriş
}

Çok uluslu imparatorluklardan milli devletlere geçiş döneminde milliyetçilik fikri yükselirken Osmanlı'dan Cumhuriyet'e geçiş sürecinde Türk milliyetçiliği güçlü bir şekilde kendini hissettirmiştir. Bu dönemde önemli bazı aydınlar tarafından Türkçülük bir kurtuluş yolu olarak görülmüştür. Milli Mücadele ve Türkiye Cumhuriyeti'nin kuruluş aşamasında da Türk milliyetçiliği devletin temel esaslarından biri olarak benimsenmiştir. Mustafa Kemal Atatürk'ün millî devlet ve millî kimlik oluşturma düşüncesi adım adım gerçekleştirilirken Türk milliyetçiliği ana eksen olmuştur. Her ne kadar 1931'de Türk Ocakları'nın kapatılması Türkçülük düşüncesinin devletin kuruluş felsefesinden uzaklaştırıldığı şeklinde bir alg1 olușturmuşsa da 1930'lar, Türk milliyetçiliğinin etkinliğinin ve yaygınlığının arttığı yıllar olmuştur. Türk Dil Kurumu, Türk Tarih Kurumu, Türk Tarih Kongreleri ve Türk Tarih Tezi gibi uygulamalar Türk kimliğine dönüşün güçlü işaretleri olmuştur. 1924 Anayasası'nda “Türkiye ahalisine din ve irk farkı olmaksızın vatandaşlık itibariyle Türk itlak olunur" denilmek suretiyle Osmanlı'dan kalma anlayışın terk edildiği ve çağdaş anlamda vatandaşlık anlayışının tercih edildiği görülmektedir. Millî devlet, millî kimlik ve vatandaşlık anlayışı 1930'larda güçlenerek gelişmeye devam etmiştir. "Vatandaş, Türkçe konuş" kampanyalarından Türk Tarih Tezi ve Güneş Dil Teorisi’ne kadar pek çok uygulama ve düzenleme Türk kimliğinin güçlenmesine katkı sağlamıştır.

II. Dünya Savaşı öncesinde "Türk ırkından olanlara" kolaylık sağlayan bazı düzenlemelerin yapıldığı, Türk olmanın öneminin vurgulandığ 1 ve resmi uygulamalarla yeni devletin "ideal yurttaş" yetiştirme faaliyetlerine hız verildiği görülmektedir. Bu dönemde eğitim ve kültürel çalışmalar aracılığıyla "milli terbiye" modeli geliştirilmeye çalışılmıştır. Yeni bir toplum fikri, modern ve milli şuura sahip birey yetiştirme düşüncesi yalnızca devletin uygulamalarında değil, dönemin aydınlarının faaliyetlerinde de görülmektedir. Dil, tarih, sanat ve kültür gibi alanlarda milli kimliğe yönelik çalışmalarda bulunan pek çok aydın bu çalışmalarıyla resmi ideolojinin meşruiyetini güçlendirmiştir.

Çağdaşlık, vatanseverlik ve milliyetçiliğin geliştirilmeye çalışıldığı bu dönemde İsmail Hami Danişmend de 1939'da Türklük dergisini çıkarmaya başlamıştır. Millet, milliyet, ırk, milliyetçilik, dil, ahlak, kültür, sanat ve tarih gibi 1930'lu yılların önemli tartışma konuları hakkında yazıların neşredildiği Türklük dergisinde Ismail Hami Danişmend, Nazan Danişmend, Ahmet Caferoğlu, Osman Turan, Refik Ahmet Sevengil, M.Şakir Ülkütaşır, Ananiasz Zayonçkovski, İsmail Habib, Naci Kum, Ali Ulvi Elöve, Abdulkadir Karahan, Stilyanos Statinopulos, Hüseyin Namık Orkun 
ve Hüseyin Sadettin Arel gibi yerli ve yabancı yazar ve Türkologların makaleleri yayınlanmıştır.

$\mathrm{Bu}$ çalışmada derginin şekil özellikleri, yazarları, makaleleri, ideolojisi ve içerik analizi ele alınarak Türk fikir hayatındaki yeri ortaya konulmaya çalışılmıştır. Ayrıca genç Türkiye Cumhuriyeti Devleti'nin kurucu ideolojisi olarak görülen Türk milliyetçiliğinin II. Dünya Savaş1 öncesi ve sırasında ülkedeki görünümü ve algılanışı İsmail Hami Danişmend'in Türklük dergisi nokta-i nazarından değerlendirilmeye çalışılmıştır.

\section{Türklük Mecmuasının Şekil Özellikleri ve Yayın Bilgileri}

İlk sayısı Nisan 1939'da Güven Basımevi tarafından İstanbul'da yayımlanan derginin, sahip ve müdürü Hüseyin Sadettin Arel $^{1}$, başmuharriri ${ }^{2}$ İsmail Hami Danişmend'dir. ${ }^{3}$ Dergi $16 \times 24 \mathrm{~cm}$ ebadında 3. hamur kağıda basılmış, kapakta karton kullanılmıştır. Dönemin şartları göz önüne alındığında kaliteli bir baskıyla okuyucunun karşısına çıkmıştır. Derginin dış kapağında büyük puntolarla "TÜRKLÜK" alt başlık olarak ise küçük puntolarla "Milliyetçi Kültür Mecmuası" yazmaktadır. İç kapakta alt başlık olarak "Ayda bir çıkar milliyetçi kültür mecmuası" ibaresi yer almıştır. Derginin idare yeri: Güven Basımevi-Cağaloğlu Yokuşu, No 14/1.'dir. ${ }^{4}$ Tüm sayılarında fiyatı 30 kuruş'tur. Senelik abonesi: memleket içinde 3 Lira, memleket dışında 5 Lira, posta birliğine girmeyen memleketler için 6 Lira şeklinde belirlenmiştir.

1 Hüseyin Sadeddin Arel, 1906'da İstanbul'da Mekteb-i Hukuk-1 Şâhâne'den birincilikle mezun olmuştur. Devletin farklı kurumlarında alanıyla ilgili görevler yapmış 1910'da Washington'da toplanan Milletlerarası Hukuk Kongresi'ne Osmanlı Devleti delegesi olarak katılmıştır. Defter-i Hakani Nazırlığı ve Şura-yı Devlet Tanzimat Dairesi reisliği gibi üst düzey görevlerde de bulunmuştur. Cumhuriyet'in ilanından sonra İzmir'de bir süre avukatlık yapmıştır. Türk Hukukçular Derneği’ni kurmuştur. Filarmoni Derneği ve İleri Türk Musikisi Konservatuvarı Derneği gibi müzikle doğrudan ilgili çalışmalarda bulunmuştur. Çocukluğundan itibaren iyi bir müzik eğitimi de alan Arel, zamanımızda Türk ve Batı musikisi alanında yetişmiş pek çok musikişinasın eğitimine büyük emek vermiştir. Türk musikisi nazariyatı üzerinde yazılmış bütün Arapça, Farsça ve Türkçe yazmaların kopyalarını kütüphanesinde bulundurmuştur. 1909-1914 yılları arasında yayınlanan Şehbal adlı magazin ve fikir mecmuasını çıkarmıştır. İsmail Hami Danişmend'le birlikte çıkardığı Türklük dergisinde de Türk musikisi üzerinde geniş ve derin makaleler yayınlamıştır. 1948'de Laika Karabey’le çıkardığı Musiki Mecmuası’nda da yine Türk müziğine dair değerlendirmelerini yayınlamıştır. Ayrıntılı bilgi için bkz. Haydar Sanal, "Arel Hüseyin Sadeddin”, TDV İslam Ansiklopedisi, C.3, İstanbul, 1991, s. 352-354

2 Ağustos 1939 tarihli 5'inci sayıdan itibaren İsmail Hami Danişmend'in ismi derginin künyesinden çıkarılmış, künyede yalnızca sahibi ve müdürü olarak Hüseyin Sadettin Arel ismine yer verilmiştir.

3 Merzifon'da doğan İsmail Hami Bey'in babası Cebeligarbi mutasarrıfı Emir Mehmed Kami Bey, annesi de Melek Hanım'dır. Şam İdadisi'nden mezun olduktan sonra İstanbul'da Mekteb-i Mülkiye'ye girmiş ve 1912'de buradan mezun olmuştur. Kısa bir süre Hariciye Nezareti'nde çalıştıktan sonra Maliye Mekteb-i Âlisi'nde tarih hocası olmuştur. Daha sonra da farklı kurumlarda tarih hocalığı yapmıştır. I. Dünya Savaşı'ndan sonra İstanbul'a dönmüş ve Mustafa Kemal Paşa tarafından çıkarılan Minber gazetesinde yazılar yazmıştır. Mütareke döneminde Memleket gazetesinde ateşli yazılar yazan İsmail Hami Bey, Sivas Kongresi'ne İstanbul delegesi olarak katılmıştır. İrade-i Milliye gazetesinde de yazılar yazmıştır. Milli Mücadele'den sonra resmi bir görev almamış ve tarih araştırmalarına yönelmiştir. Nisan 1939'da Türklük dergisini çıkaran İsmail Hami Danişmend, Türk kültürüne hizmet etmiş ve pek çok önemli esere imza atmıştır. 12 Nisan 1967'de vefat etmiştir. Ayrıntılı bilgi için bkz. Cevdet Küçük, "Danişmend, İsmail Hami", TDV Íslam Ansiklopedisi, C.8, İstanbul, 1993, s. 465-467; Mustafa Alkan - Adnan Gül, "İsmail Hami Danişmend (1889-1967)", Türk Yurdu, Ocak 2011, Y1l 100, S. 281, s. 131-136; Erkan Cevizliler, "Sivas Kongresi Divan-1 Riyâset Kâtibi İsmail Hami (Dânişmend)", Atatürk Dergisi, C:3, Şubat 2010, s.203-217.

4 Derginin 1 Temmuz 1939 tarihli 4'üncü sayısının iç kapağında idare yeri olarak Yeni Postahane arkasında (Kısmet Han), No.26-27 Tel.24016 adresi verilmiştir. Bu şekilde daimi idare kurulduğu belirtilmektedir. 
Bir kaynakta derginin 10 sayı yayınlandığ $1^{5}$ ifade edilirken başka bir kaynakta ise 14 sayı olarak yayınlandığı belirtilmiştir. ${ }^{6}$ Esasen son sayının kapağında "14-15” yazılıdır. 13'üncü sayı 48 sayfa olarak çıkarılmışken bu son sayı 64 sayfa olarak neşredilmiştir. Her ne kadar hacmi iki sayılık sayfayı muhtevi olmasa da iki sayının birlikte çıkarıldığını gösteren kapağa bakılarak 15 sayı halinde yayınlandığının kabul edilebileceği düşünülmektedir. Bu şekilde dergi, 3 cilt ve 15 sayı olarak Nisan 1939-Ikinciteşrin (Kasım) 1940 tarihleri arasında yayın hayatını sürdürebilmiştir. Dergi aylık olarak yayınlanmış, Nisan 1940 tarihinde 13'üncü sayısından sonra 6 ay basımına ara verilmiş, 14 ve 15'inci sayılar birleşik olarak son kez Kasım 1940'da basılmıştır. Dergi sayılarının yayımlanma tarihi ve derginin sayfa sayısına ilişkin ilişkin tablo aşağıdadır:

\section{Tablo 1: Basim Bilgileri}

\begin{tabular}{c|r|r|r|r} 
Cilt & Sayı & Yayım Tarihi & Sayfa No & Sayfa Sayısı \\
\hline I & 1 & Nisan 1939 & $1-80$ & 80 \\
\hline I & 2 & 1 Mayıs 1939 & $81-168$ & 88 \\
\hline I & 3 & 1 Haziran 1939 & $169-248$ & 80 \\
\hline I & 4 & 1 Temmuz 1939 & $249-336$ & 88 \\
\hline I & 5 & Ağustos 1939 & $337-416$ & 80 \\
\hline I & 6 & 1 Eylül 1939 & $417-496$ & 80 \\
\hline II & 7 & Birinciteşrin 1939 & $1-72$ & 72 \\
\hline Birinci Cildin Fihristi & - & - & $1-4$ & 4 \\
\hline II & 8 & İkinciteşrin 1939 & $73-144$ & 72 \\
\hline II & 9 & Birincikânun 1939 & $145-208$ & 64 \\
\hline II & 10 & İkincikânun 1940 & $209-272$ & 64 \\
\hline II & 11 & 1 Şubat 1940 & $273-325$ & 52 \\
\hline II & 12 & 31 Mart 1940 & 325 -374 & 50 \\
\hline III & 13 & 30 Nisan 1940 & $375-422$ & 48 \\
\hline III & $14-15$ & İkinciteşrin 1940 & $423-487$ & 64
\end{tabular}

Görüldüğ̈ü gibi 6'ncı sayı 496'ncı sayfa ile bitirilerek I. cilt tamamlanmıştır. II. cildin sayfa numarası ise 497 'den değil, 1 'inci sayfadan başlatılmıştır. III. cilt, II. cildin sayfa numarasını takip ederek 375'ten devam etmiştir. Derginin birinci cildi (1-6'ıncı sayılar), henüz II. Dünya Savaşı'nın olumsuz ekonomik koşulları ülke ekonomisine yansımadığı için en az seksen sayfa olarak düzenlenmiş, çok sayıda fotoğrafa yer verilmiştir. İkinci cilde geçildiğinde kağıt tedariki konusunda sıkıntılar artmaya başlamış bu da derginin sayfa sayılarında azalmaya neden olmuştur. Ayrıca 12'nci sayıya gelindiğinde sayfa sayısının 50'ye kadar gerilediği görülmektedir. Dergi genellikle ayın ilk günü piyasaya çıkmakla beraber, 7'nci ve 8'inci nüshaları "kağıt tedarikindeki müşkülattan dolayı" gecikmiş, bunun için itizar başlığıyla özür dilenmiştir." 10'uncu sayıda 'bundan sonra mecmuamız her ayın sonunda çıkacaktır" notu paylaşılarak yayımlanma tarihi değiştirilmiştir. Derginin "sahip ve müdürü" Hüseyin Sadettin Arel'in "Türk Musikisi Kimindir?" başlığıyla yayınlanan 14 makalesinin son sayıya kadar sürmesi dikkat çekicidir. Makale dizisi tamamlandığında dergi yayın hayatını devam ettirememiştir. Derginin yayın hayatının sonlandırılmasına ilişkin herhangi bir açıklamaya ulaşılamamıştır. Derginin son notunda "Türkiye Maarif Tarihi: İstanbul Vilayetinin kıymetli mektupçusu değerli âlimlerimizden Osman'ın ${ }^{8}$ bu mühim ve büyük eserinin ikinci cildi hakkında gelecek nüshamızda bir etüd bulunacaktır." ibaresi yer almıştır. Bu ifadeden anlaşılan, derginin 16'ıncı sayısına yönelik bir hazırlık yapılmış ama söz konusu baskı gerçekleşememiştir.

5 Ferudun Ata, İsmail Hami Danişmend'in “Irk” Üzerine Bazı Tespitleri”, Tarihin Peşinde, S. 9, Yı1, 2013, s. 75

6 Ömer Özcan, “Milliyetçi Kültür Dergisi Türklük”, Türk Yurdu, S. 213, Mayıs 2005, s. 111-112

7 Bkz. Türklük, C.2, S.8, İkinciteşrin (Kasım) 1939, iç kapak

8 Osman Nuri Ergin 


\section{Derginin Amacı ve Yayın Politikası}

Derginin ilk sayısının ilk sayfalarında TÜRKLÜK imzası taşıyan "Mesleğimiz" başlıklı bir yazı kaleme alınmıştır. Bu yazıda, derginin başlığında yer alan "Milliyet ve Kültü̈r" kelimelerine işaret edilerek açıklamalar yapılmıştır. Milliyet kelimesinin "1rk", "dil”, "kültür", "tabiiyet" ve "Turanlılık” gibi kavramlarla karşılanmaya çalışıldığının ifade dildiği yazıda millet tanımında da ırk birliği, dil birliği, kültür birliği ve din birliği gibi ölçülerin hiçbirinin zaruri olmadığı ifade edilmiștir. Millet kavramı burada "herhangi bir esas etrafında toplanmış mütesanit bir insan kütlesi" olarak tanımlanmıștır. Tanımlamalar ve karşılaștırmalardan sonra yazıda "on dokuzuncu asır Türkologlarının bugünkü ilimde hiçbir kıymeti kalmamış bir takım istidlâller üzerini kurdukları itibari bir Turan grubu" ve "antropoloji ve etnoloji bakımından ırk esasına göre değil, lisaniyat bakımından sun'i ve tahmini karabet faraziyesine istinat ettirilmişti!" ifadeleriyle bir Turancilık reddiyesinde bulunulmuştur. ${ }^{10}$ Kavramların ve kelimelerin ilmî manasının da ele alındığı yazıda ayrıca şunlar dile getirilmiştir:

"Millet ve Milliyet kelimelerinin ilmi manalarıla halkın kabul ettiği umumi manaları arasında çok büyük bir fark vardır. Bizde halk, milliyet tabirini milli duygu ve millete mensubiyet gibi manalarda kullanır... Ilimde milliyet demek bir nevi cemiyet demektir. Fakat bu cemiyet millet gibi yalnız 'bir esas etrafinda toplanmış mütesanit bir kütle'den ibaret değildir. Herhangi bir cemiyetin milliyet sayılması için efradının birbirlerine ırk, dil, din, vatan, kültür ve tarih gibi muhtelif bağların hepsiyle birden bağlı olması lazım gelir... Illmin bu esasına göre siyasi bir cemiyet olan millet sonradan teşekkül etmiş mazisiz bir kütleden ibaret olduğu halde milliyet maziden çıkıp hale uğrayarak istikbale giden ve gidiş kuvvetini siyasetten değil, tabiattan alan bir cemaat demektir. En sağlam cemiyetler bunlardır. Avrupa cemiyetleri bu bakımdan iki gruba ayrlabilir: Fransa, Ísviçre, Belçika vesaire gibi milletlere mukabil, Macar, Fin, Alman vesaire milliyetleri. Türkiye'de Tanzimat ve Meşrutiyet Türkçülerinin yanıldıkları nokta, işte bu vaziyeti göremeyerek bir zaman Turancılık etmeleri ve ondan sonra da bir milliyet ideolojisi yerine Fransiz kültürünün tesiriyle bir millet ideolojisi kurmak istemeleridir. Fakat Türkiye Türklügü bir millet değil, bir milliyettir. 'Türklük' milli bir kültür mecmuası sıfatıyla ilmî milliyetin ilmî manasını kabul etmiştir. Irk, dil, kültür gibi çeşitli izahlara bu ilmî manada taraftar olanlar, bu esasları ilmin tayin ettiği toplu anlamıyla birleşmiş bulacaklardır. 'Türklük' milliyetçi olduğundan dolayı ırkçı, dilci, kültürcü ve vatancıdır." "B Bu yazıdaki ifadeler ve fikirler, İsmail Hami Danişmend'in kaleme aldığı "Eski Şark ve Yeni Garp Telakkilerine Göre: Irk nedir?" 12 başlıklı yazıdaki ifade ve düşüncelerle örtüşmekte olduğundan, "Mesleğimiz" isimli makaleyi de onun yazdığı değerlendirilmektedir.

Türklük'ün çıkarılıș amacı bu şekilde ifade edilirken yayın politikasında da günlük siyasi mülahazalardan uzak kalındığı vurgulanmıştır. Derginin 10'uncu sayısında yer alan "Türkiye" isimli makalenin takdim kısmında: "Mecmuamızın siyasetle alakası olmadığı için, bu güzel yazıda tesadüf ettiğimiz bazı siyasi fikraları tercümeye lüzum görmedik. Zaten bu makalenin bütün güzelliği, tarihle kültüre ait kısımlarında toplanmaktadır: Siyasetten bahseden kisımları miktar itibariyle de bunlardan da daha azdır" 13 denilmektedir. Esasen bu ifadeler yalnizca bu makaleyle sınırlı değildir; derginin güncel siyasi meselelere hiç girmeyen, tarih ve kültürle sınırlı yayın politikasını diğer tüm makalelerde de görebilmek mümkündür. Dergi, hiçbir sayısında güncel siyasi tartışmalara girmemiş, siyasi konulara taraf olmamıştır. Bununla birlikte tek parti iktidarının önemli müesseselerinden Halkevlerinde İsmail Hami Danişmend ve diğer yazarlar tarafından

\footnotetext{
9 Yazınının içeriğinden, yazıyı derginin başmuharriri İsmail Hami Danişmend’in kaleme aldığ1 düşünülmektedir.

10 "Mesleğimiz", Türklük, S.1, Nisan 1939, s.2

11 "Mesleğimiz", Türklük, S.1, Nisan 1939, s.3-4

12 İsmail Hami Danişmend, “Eski Şark ve Yeni Garp Telakkilerine Göre: Irk Nedir?”, Türklük, S.1, Nisan 1939, s. 39-57

13 Paul Achard, “Türkiye”, Türklük, S.10, İkincikanun (Ocak) 1940, s. 226
} 
verilmiş konferanslar dergide basılmıştır. ${ }^{14}$ Ancak bunların da gündelik siyasi meseleler olmadığını belirtmek gerekir.

Ayrıca tamamı incelendiğinde derginin Türk dili, Türk edebiyatı, Türk ırk1, Türk sanatı, Türk tarihi ve Türk kültürü üzerinde özellikle durduğu anlaşılmaktadır. "Irkçı, dilci, kültürcü ve vatancı" bir mecmua olan Türklük, ilmî bir yaklaşımla Türklüğe ve Türk kültürüne hizmet eden bir yayın politikası takip etmiştir.

\section{Türklük Mecmuasının Genel Özellikleri ve Yazar Kadrosu}

Dergide tarih, dil, kültür, folklor, tiyatro, müzik, şiir ve edebiyat gibi farklı alanlardan yazarların makalelerine yer verilmiştir. Yazar kadrosu incelendiğinde dönemin münevverlerinden birçok insana rastlandıği gibi müteveffa tarihî şahsiyetlerin eserleri de yayımlanmıştır.

Yazar kadrosundan ilk anılması gereken isim İsmail Hami Danişmed'dir. İsmail Hami Danişmend, başyazar olarak dergide en çok yazısı basılan yazardır. ${ }^{15}$ Sahibi ve müdürü gözüken Hüseyin Sadettin Arel'in, Türk Musikisi Kimindir? makale dizisi 14 bölüm halinde derginin bütün sayılarında yayınlanmıştır. Dergide birden fazla yazısı neşredilen diğer yazarlar: Hüseyin Namık Orkun, Nazan Danişmend ${ }^{16}$, Ahmet Caferoğlu, Osman Turan, Refik Ahmet Sevengil, M. Şakir Ülkütaşır, Naci Kum, Ali Ulvi Elöve, Abdülkadir Karahan, Stilyanos Stasinopulos, Ananiasz Zajaczkowski ${ }^{17}$, V.Y. Muçoğlu olmuşlardır. Yazar olarak gösterilen, Eğinli Sait Paşa ${ }^{18}$, Abdülhak Hamit, Hayrullah Efendi (Abdülhak Hamit' in babas1), Hoca Naum müteveffadır. Dergide yabanc1 uyruklu Türkologlara ve bilim insanlarının yazılarına da yer verilmiştir. Ayrıca Ismail Hami Danişmend, Türkiye ve Türk tarihi meseleleriyle ilgili yabancı makalelerden çeviri yaparak yayınlamıştır.

Bölümlendirilerek yayımlanan Abdülhamit'in mabeyn müşiri Eğinli Sait Paşa'nın hatıratı, Danişmend ailesinin kişisel tanışıklığı bulunan Abdülhak Hamit Tarhan'ın biyografisi ve şiirleri, yine Hamit' in babası Hayrullah Efendi'nin hayatı ve çevirdiği piyesler de dergide önemli ölçüde yer tutmuştur. Dergide çok sayıda Abdülhak Hamit ve Eğinli Sait Paşa'ya ilişkin fotoğraf bulunmaktadır. Dergide Süryani Mikail vakayinamesi ile Vriyennios Vakayinamesi, çevrilerek ya da daha önce çevrildiği şekliyle tekrar yayınlanmıştır. Dergide editoryal bir tercih olarak Bursa tarihi hakkında beş yazı yayımlanmıştır. Dedem Korkud Eseri ve yazarı Orhan Şaik Gökyay’a yönelik tenkitler dergide birden fazla ele alınan konu başlıklarından olmuştur. Derginin sahibi ve müdürü Hüseyin

14 Bknz: İsmail Hami Danişmend, “Osmanlıların Aslı Meselesi: I, Osman Gazi'nin Nesep ve Hüviyeti”, Türklük, S.3, 1 Haziran 1939, s. 207-223; Nazan Danişmed, "Tarih ve Edebiyatta: Türk Güzelliği”, Türklük, S.3, 1 Haziran 1939, s. 69-84; Selim Nüzhet Gerçek, "Hayalin" Hakikati”, Türklük, S.8, İkinciteşrin (Kasim)1939, s. 92-98

15 İsmail Hami Danişmend, derginin 11'inci sayısı hariç tüm sayılarında yazı yazmıştır.

16 İsmail Hami Bey’in eski bir öğrencisi ve eşi olan Nazan Danişmend, Eğinli Sait Paşa ve Abdülhak Hamid ile ilgili makaleler neşretmiştir. Evlenmelerinden bir süre sonra İsmail Hami Bey’le birlikte Fethi Ahmet Paşa korusundaki büyük köşke taşınmışlardır. Fethi Ahmet Paşa, II. Mahmut'un kızı ve Sultan Abdülmecid'in kardeşi Atiye Sultan ile evlenmesinden dolayı damat olarak anılmaktadır. Nazan Hanım da Fethi Ahmet Paşa'nın torunudur. İlk defa olarak Türk çocuklarını devlet adına Fransa ve İngiltere'ye gönderilmesini sağlayan Fethi Ahmet Paşa, o dönemde Eğinli Sait Efendi'yi de İngiltere'ye göndermiştir. Daha sonra kızını Sait Efendi’yle evlendirmiştir. Nazan Hanım da Eğinli Sait Paşa'nın oğlu Memduh Bey’in kızıdır. Nazan Danişmend, Tanzimat’ın ilanının 100. yılı dolayısıyla Mabeyn Müşiri ve Bahriye Nazırı Eğinli Sait Paşa hakkında bir biyografi kaleme almıştır. Biyografi yazısından sonra dönemin en mühim vesikalarından biri olan ve dedesi Eğinli Sait Paşa’nın el yazması olarak 7 defterde bulunan hatıralarından bazı kısımlar Türklük’te yayınlanmıştır. Bkz. Ömer Özcan, "Milliyetçi Kültür Dergisi Türklük", Türk Yurdu, S. 213, Mayıs 2005, s. 111-112

17 Yazarın eserlerinin Türkçe çevirilerinin İsmail Hami Danişmend tarafından yapıldığı düşünülmektedir.

18 Eğinli Sait Paşa Hatıratı’nın torunu Nazan Danişmend ve İsmail Hami Danişmend tarafından yayına hazırlandığı düşünülmektedir. 
Sadettin Arel'in dergi yayın hayatına son verene kadar yayımlanan "Türk Musikisi Kimindir?" yazı dizisi 14 bölüm halinde yayımlanmıştır. Önce Türklük, daha sonra Musiki Mecmuası'nda olmak üzere iki defa tefrika edilen bu eser kitap olarak da neşredilmiştir. Dergide ayrıca yabancı dilde (Fransızca) tek makale ${ }^{19}$ yayınlanmıştır. Bu makale de Macar müsteşriklerden Alexandre Eckhardt tarafından Truvalıların Türklüğünü muhtevidir.

Tablo 2: I. Cilt Yazar kadrosu ve makale sayıları

\begin{tabular}{|c|c|c|c|}
\hline Yazar & Yaşı & Alani/Mesleği & Makale Sayısı \\
\hline Abdülhak Hamit & Müteveffa & Şair, tiyatro yazarı & 1 \\
\hline Ahmet Ağaoğlu & 70 & Gazeteci, siyasetçi & 1 \\
\hline Ahmet Caferoğlu & 40 & Türk dilbilimci & 3 \\
\hline Ali Ulvi Elöve & 58 & Şair, öğretmen, çevirmen, dilbilimci & 1 \\
\hline A. Zayonçkovski & $?$ & Türkoloji Profesörü & 3 \\
\hline Eğinli Sait Paşa & Müteveffa & II. Abdülhamit'in mabeyn müşiri & 3 \\
\hline Hayrullah Efendi & Müteveffa & Reisületıbba, devlet adamı, eğitimci, edip ve şair & 1 \\
\hline Hüseyin Namık Orkun & 37 & Tarihçi, fikir adamı & 11 \\
\hline Hüseyin Sadettin Arel & 59 & Türk musikisi bilgini, bestekâr ve hukukçu & 6 \\
\hline İsmail Habip Sevük & 47 & Edebiyat tarihçisi, eğitimci ve yazar & 1 \\
\hline İsmail Hami Danişmend & 40 & Tarihçi ve Türk Dili araştırmacısı & 13 \\
\hline $\begin{array}{l}\begin{array}{l}\text { Mahmut Ragıp Kösemihal } \\
\text { (Gazinihal) }\end{array} \\
\end{array}$ & 39 & Türk musikisi eğitimcisi, araştırmacı ve tarihçi & 1 \\
\hline Mehmet Şakir Ülkütaşır & 45 & Türk halkbilimci & 2 \\
\hline Nazan Danişmend & $29 ?$ & Türk tarihçisi, Türk dilbilimci, İ.H.D’nin eşi & 5 \\
\hline Nureddin Ardıç (Ardıçoğlu) & 26 & Eğitimci, hukukçu, gazeteci, siyasetçi (bakan) & 1 \\
\hline Osman Nuri Sumer & $?$ & Okuyucu & 1 \\
\hline Osman Turan & 25 & Türk tarihçisi, fikir ve siyaset adamı & 1 \\
\hline Peyami Safa & 40 & Romanc1, gazeteci ve fikir adamı & 1 \\
\hline Refik Ahmet Sevengil & 36 & Gazeteci, roman, hikâye ve inceleme yazarı & 1 \\
\hline Şüküfe Nihal Başar & 33 & Şair, öğretmen, aktivist & 1 \\
\hline TÜRKLÜK & - & - & 7 \\
\hline
\end{tabular}

Tablo 2: II. Cilt Yazar kadrosu ve makale sayıları

\begin{tabular}{l|c|l|c} 
Yazar & Yaşı & Alanı/Mesleği & Makale Sayısı \\
\hline Abdülkadir Karahan & 26 & Türk Edebiyatçısı & 1 \\
\hline Ahmet Caferoğlu & 40 & Türk dilbilimci & 1 \\
\hline Alexandre Eckhardt & $?$ & Macar Tarihçi, Türkolog & 1 \\
\hline Ali Ulvi Elöve & 58 & Şair, öğretmen, çevirmen, dilbilimci & 1 \\
\hline Atıf Bayındır & 46 & Mülkiye Mezunu Siyasetçi & 1 \\
\hline Cahide Başol & $?$ & Okuyucu & 1 \\
\hline Cevat Hakkı Tarım & 46 & Gazeteci, Tarihçi ve Siyasetçi & 1 \\
\hline Eğinli Sait Paşa & Müteveffa & II. Abdülhamit'in mabeyn müşiri & 3
\end{tabular}

19 Par Alexandre Eckhardt, "La Légende de l'origine Troyenne des Turcs", Türklük, C.2, S. 12, 31 Mart 1940, s.330-339 


\begin{tabular}{|c|c|c|c|}
\hline Giyas Sağer & $?$ & Araştırmacı & 1 \\
\hline Hayrullah Efendi & Müteveffa & Reisületıbba, devlet adamı, eğitimci, şair & 2 \\
\hline Hoca Naum & Müteveffa & Tiyatro ve Operacı & 1 \\
\hline Hüseyin Namık Orkun & 37 & Tarihçi, fikir adamı & 3 \\
\hline Hüseyin Sadettin Arel & 59 & Türk musikisi bilgini, bestekâr ve hukukçu & 6 \\
\hline İsmail Hami Danişmend & 40 & Tarihçi ve Türk dili araştırmacısı & 11 \\
\hline Jean Deny & $?$ & Dilbilimci, Türkolog & 1 \\
\hline V.Y. Muçooğlu & $?$ & Tarihçi, çevirmen & 2 \\
\hline Naci Kum & 43 & Bursa Müze Müdürü & 1 \\
\hline Nazım Yücelt & $?$ & Bursa Erkek Lisesi tarih öğretmeni & 1 \\
\hline Osman Turan & 25 & Türk tarihçisi, fikir ve siyaset adamı & 2 \\
\hline Paul Achard & $?$ & Gazeteci & 1 \\
\hline Refik Ahmet Sevengil & 36 & Gazeteci, roman, hikaye ve inceleme yazarı & 1 \\
\hline Rıza Ruşen Yücer & $?$ & Bursalı gazeteci & 1 \\
\hline (Ali) Riza Yalgın & 41 & Adana Müze Müdürü & 1 \\
\hline Selim Nüzhet Gerçek & 48 & Türk matbaacılığı, gazeteciliği ve tiyatrosu yazarı & 1 \\
\hline Stilyanos Stasinopulos & $41 ?$ & Maden mühendisi & 1 \\
\hline Yusuf Ziya Demirci (oğlu) & 42 & Konservatuar müdürü & 1 \\
\hline Zeki Ömer Defne & 36 & Şair, öğretmen & 1 \\
\hline TÜRKLÜK & - & - & 3 \\
\hline
\end{tabular}

Tablo 3: III. Cilt Yazar kadrosu ve makale sayıları

\begin{tabular}{l|c|lcc} 
Yazar & Yaşı & Alanı/Mesleği & Makale Sayısı \\
\hline Abdülkadir Karahan & 26 & Türk Edebiyatçısı & 1 \\
\hline Ali Kâmı Akyüz & 66 & Şair, Yazar, Siyasetçi, Peyami Safa'nın amcası & 1 \\
\hline Eğinli Sait Paşa & Müteveffa & II. Abdülhamit’in mabeyn müşiri & 1 \\
\hline Hüseyin Namık Orkun & 37 & Tarihçi, fikir adamı & 1 \\
\hline Hüseyin Sadettin Arel & 59 & Türk musikisi bilgini, bestekâr ve hukukçu & 2 \\
\hline İsmail Hami Danişmend & 40 & Tarihçi ve Türk dili araştırmacısı & 3 \\
\hline V.Y. Muçooğlu & $?$ & Zağrofyan Rum Lisesi Müdürü & 1 \\
\hline Naci Kum & $?$ & Bursa Müze Müdürü & 1 \\
\hline Reşit Saffet Atabinen & 45 & Siyasetçi & 1 \\
\hline Sadettin Nüzhet Ergun & 39 & Türk edebiyatı tarihçisi, Hallaç Baba Sâdî Dergâhı & 1
\end{tabular}

\section{Türklük Mecmuasının Muhtevası}

Dergide Türk musikisi, edebiyat, tiyatro, dil, kültür, eski kitabe çevirileri, folklor, etnoğrafya, eski Türklerin bayrak ve armaları, şiir, biyografi, kitap ve dergi tanıtımları, eski tarihi vesikalar gibi çeşitli içerikte yazılar bulunmaktadır. Așağıda yer alan tabloda dergide yayımlanmış yazıların özet içerikleri bulunmaktadır. 
Tablo 4: Dergi makaleleri ve özet içerikleri

\begin{tabular}{|c|c|c|c|c|c|c|}
\hline Yazar Adı & Tür & Konu & Makale & Cilt & Sayı & $\begin{array}{l}\text { Sayfa- } \\
\text { Aralığı }\end{array}$ \\
\hline $\begin{array}{l}\text { A. Zayonçkovski } \\
\text { (Ananiasz } \\
\text { Zajaczkowski) }\end{array}$ & $\begin{array}{l}\text { Araştırma- } \\
\text { Inceleme }\end{array}$ & $\begin{array}{l}\text { Marbuzan-name Farsçadan aktarılmış bir } \\
\text { eserdir. Hayvan hikâyelerine dayanan konusu } \\
\text { ile olduğu kadar, akıcı, etkileyici sade dil } \\
\text { ve üslubu ile de Türk Dili ve Edebiyatı'nın } \\
\text { üstün nitelikli eserleri arasına girmiştir. Prof. } \\
\text { Zayonçkovski'nin el yazısıyla Marbuzan- } \\
\text { name'den istihsal edilmiş "Serçe ile Leklek" } \\
\text { masalına da yer verilmiștir. }\end{array}$ & $\begin{array}{l}\text { Anadolu Türk } \\
\text { edebiyatının XIV üncü } \\
\text { asra ait mühim bir } \\
\text { vesikası: Marzuban- } \\
\text { name }\end{array}$ & 1 & 1 & $5-12$ \\
\hline $\begin{array}{l}\text { A. Zayonçkovski } \\
\text { (Ananiasz } \\
\text { Zajaczkowski) }\end{array}$ & $\begin{array}{l}\text { Araştırma- } \\
\text { Inceleme }\end{array}$ & $\begin{array}{l}\text { Lehistan'da yerleşik Türk ırkına } \\
\text { mensup bulunan "Tatar ve Karaim"den } \\
\text { bahsedilmektedir. }\end{array}$ & $\begin{array}{l}\text { Lehistan arazisinde } \\
\text { Türk unsurlart-I }\end{array}$ & 1 & 5 & $338-344$ \\
\hline $\begin{array}{l}\text { A. Zayonçkovski } \\
\text { (Ananiasz } \\
\text { Zajaczkowski) }\end{array}$ & $\begin{array}{l}\text { Araştırma- } \\
\text { Inceleme }\end{array}$ & $\begin{array}{l}\text { Lehistan'da yerleșik Türk ırkına } \\
\text { mensup bulunan "Tatar ve Karaim"den } \\
\text { bahsedilmektedir. }\end{array}$ & $\begin{array}{l}\text { Lehistan arazisinde } \\
\text { Türk unsurlart-II }\end{array}$ & 1 & 6 & $417-424$ \\
\hline Abdülhak Hamit & Şiir & Abdülhak Hamit'in son şiirlerinden biridir. & Gazup bir şair & 1 & 2 & $100-109$ \\
\hline $\begin{array}{l}\text { Abdülkadir } \\
\text { Karahan }\end{array}$ & $\begin{array}{l}\text { Araştırma- } \\
\text { Inceleme }\end{array}$ & $\begin{array}{l}\text { Fuzuli'nin nesir alanındaki meşhur eseri } \\
\text { Hadikat-üs Suadası incelenmiştir. }\end{array}$ & $\begin{array}{l}\text { Fuzuli'nin Hadikat-üs } \\
\text { Suadası }\end{array}$ & 2 & 7 & $20-28$ \\
\hline $\begin{array}{l}\text { Abdülkadir } \\
\text { Karahan }\end{array}$ & $\begin{array}{l}\text { Araştırma- } \\
\text { Inceleme }\end{array}$ & $\begin{array}{l}\text { Şiirlerinden örneklerle Fuzuli'nin lirik, } \\
\text { samimi, melal ve merarete mütemayil fakat } \\
\text { ümitle kalbi aydınlanmış, feragat sahibi, } \\
\text { saf ve en heyecanlı anlarında bile mümkün } \\
\text { mertebe şuurunu müdrik en büyük Türk } \\
\text { sanatkârı olduğu anlatılmaktadır. }\end{array}$ & $\begin{array}{l}\text { Fuzuli'nin şiiri ve } \\
\text { şahsiyeti hakkında }\end{array}$ & 3 & 13 & $418-422$ \\
\hline Ahmet Ăgaoğlu & $\begin{array}{l}\text { Arassttrma- } \\
\text { Inceleme }\end{array}$ & $\begin{array}{l}\text { Türk Dili hakkında okuyuculara arz } \\
\text { edilecek tetkiklerin ve bu tetkiklerden } \\
\text { alınan neticelerin orijinalitesini göstermek, } \\
\text { zamanımıza kadar Avrupa ilim âleminde } \\
\text { kabul edilmiş olan nazariyeleri kısa bir } \\
\text { șekilde arz etmek. }\end{array}$ & Lisaniyat & 1 & 3 & $185-188$ \\
\hline Ahmet Caferoğlu & $\begin{array}{l}\text { Araştırma- } \\
\text { Inceleme }\end{array}$ & $\begin{array}{l}\text { Anadolu etnografya meselelerinden } \\
\text { Afyonkarahisar ilinde küme halinde yerleşmiş } \\
\text { bulunan Anadolu-Azeri Trüklerinin mahalli } \\
\text { ağızları hakkında bilgi verilmiştir. }\end{array}$ & $\begin{array}{l}\text { Afyonkarahisar } \\
\text { Azerileri }\end{array}$ & 1 & 1 & $23-28$ \\
\hline Ahmet Caferoğlu & $\begin{array}{l}\text { Araştırma- } \\
\text { Inceleme }\end{array}$ & $\begin{array}{l}\text { Anadolu ve Azerbaycan çocuk kültüründeki } \\
\text { Şamanizm etkisi incelenmiştir. }\end{array}$ & $\begin{array}{l}\text { Anadolu ve } \\
\text { Azerbaycan Çocuk } \\
\text { Folkloründe Şamanizm } \\
\text { Bakiyyesi }\end{array}$ & 1 & 2 & 144-149 \\
\hline Ahmet Caferoğlu & $\begin{array}{l}\text { Araştırma- } \\
\text { Inceleme }\end{array}$ & $\begin{array}{l}\text { Azeri Türklerinin hayatında mühim roller } \\
\text { oynayan ve oynamış olan batıl itikatlar } \\
\text { hakkında bilgi verilmiştir. }\end{array}$ & $\begin{array}{l}\text { Azeri Türk Hayatında } \\
\text { Batıl İtikatlar }\end{array}$ & 1 & 3 & 194-206 \\
\hline Ahmet Caferoğlu & $\begin{array}{l}\text { Araştırma- } \\
\text { Inceleme }\end{array}$ & $\begin{array}{l}\text { Ural-Altay dil grubu hakkındaki bilimsel } \\
\text { çalışmalara yer verilmiştir }\end{array}$ & $\begin{array}{l}\text { "Ural-Altay" Dilleri } \\
\text { Mektebi ve Türkoloji }\end{array}$ & 2 & 7 & $35-44$ \\
\hline $\begin{array}{l}\text { Alexandre } \\
\text { Eckhardt }\end{array}$ & $\begin{array}{l}\text { Araştırma- } \\
\text { Inceleme }\end{array}$ & Truvalıların Türklüğ̈̈ & $\begin{array}{l}\text { La légende de l'origine } \\
\text { Troyenne des Turcs } \\
\text { (Fransizca) }\end{array}$ & 2 & 12 & $332-339$ \\
\hline Ali Kami Akyüz & Biyografi & $\begin{array}{l}\text { Ölümünün kırkıncı yılı dolayısıyla İsmail } \\
\text { Safa hakkında bir tezkireye yer verilmiștir. }\end{array}$ & İsmail Safa & 3 & 13 & $389-393$ \\
\hline
\end{tabular}




\begin{tabular}{|c|c|c|c|c|c|c|}
\hline Ali Ulvi Elöve & $\begin{array}{l}\text { Araştırma- } \\
\text { Inceleme }\end{array}$ & $\begin{array}{l}\text { Namık Orkun'un "Kemçik-Cırgak yazıtı" } \\
\text { yazısı tenkit edilmekte, Orhon, Yenisey, } \\
\text { Çakul kitabelerindeki harf ve kelimeler } \\
\text { karşılaştırılarak analiz yapılmaktadır }\end{array}$ & $\begin{array}{l}\text { Yenisey Kitabeleri } \\
\text { Üzerine Bazı } \\
\text { Araştırmalar: Yaruk } \\
\text { Tigin-Çakul Kitabesi }\end{array}$ & 1 & 5 & $358-366$ \\
\hline Ali Ulvi Elöve & $\begin{array}{l}\text { Araştırma- } \\
\text { Inceleme }\end{array}$ & $\begin{array}{l}\text { "Lûgat-ı Çagatayî ve Türkî̀-i Osmanî" } \\
\text { kitabının tanıtımı ve analizi yapılmıştır. }\end{array}$ & $\begin{array}{l}\text { "Lûgat-ı Çagatayî ve } \\
\text { Türkî-i Osmanî" zeyli }\end{array}$ & 2 & 8 & 140-144 \\
\hline Atıf Bayındır & Tercüme & $\begin{array}{l}\text { R. V. Elmayer'in makalesinin tercümesidir. } \\
\text { Sümer devrinde bira yapımı ve tüketimi } \\
\text { hakkında bilgiler verilmektedir. }\end{array}$ & $\begin{array}{l}\text { Sümerliler Devrinde } \\
\text { Bira ve Bira Imali }\end{array}$ & 2 & 7 & $63-69$ \\
\hline Cahide Başol & $\begin{array}{l}\text { Araştırma- } \\
\text { Inceleme }\end{array}$ & $\begin{array}{l}\text { Ahmet Caferoğlu'nun "Batıl İtikatlar" yazısı } \\
\text { üzerine açılan konuya katkı sunmaktadır. }\end{array}$ & $\begin{array}{l}\text { İstanbul'da Bazı Batıl } \\
\text { İtikatlar }\end{array}$ & 2 & 9 & 179-185 \\
\hline $\begin{array}{l}\text { Cevat Hakkı } \\
\text { Tarım }\end{array}$ & $\begin{array}{l}\text { Araştırma- } \\
\text { Inceleme }\end{array}$ & $\begin{array}{l}\text { Kırşehir ve çevresindeki yer adları } \\
\text { incelenmiştir. }\end{array}$ & $\begin{array}{l}\text { Yer Adları Bakımından } \\
\text { Kırşehir }\end{array}$ & 2 & 11 & 293-295 \\
\hline Eğinli Sait Paşa & Hatıra & $\begin{array}{l}\text { II. Abdülhamit'e en yakın isimlerden mabeyn } \\
\text { müşiri Eğinli Sait Paşanın hatıratıdır. }\end{array}$ & Hatırat & 1 & 4 & $263-269$ \\
\hline Eğinli Sait Paşa & Hatira & $\begin{array}{l}\text { II. Abdülhamit'e en yakın isimlerden mabeyn } \\
\text { müşiri Eğinli Sait Paşanın hatıratıdır. }\end{array}$ & Hatırat & 1 & 5 & $400-403$ \\
\hline Ĕ̆inli Sait Paşa & Hatıra & $\begin{array}{l}\text { II. Abdülhamit'e en yakın isimlerden mabeyn } \\
\text { müşiri Eğinli Sait Paşanın hatıratıdır. }\end{array}$ & Hatırat & 1 & 6 & $472-476$ \\
\hline Eğinli Sait Paşa & Hatira & $\begin{array}{l}\text { II. Abdülhamit'e en yakın isimlerden mabeyn } \\
\text { müşiri Eğinli Sait Paşanın hatıratıdır. }\end{array}$ & Hatırat & 2 & 7 & $70-72$ \\
\hline Eğinli Sait Paşa & Hatıra & $\begin{array}{l}\text { II. Abdülhamit'e en yakın isimlerden mabeyn } \\
\text { müşiri Eğinli Sait Paşanın hatıratıdır. }\end{array}$ & Hattrat & 2 & 8 & $138-139$ \\
\hline Eğinli Sait Paşa & Hatira & $\begin{array}{l}\text { II. Abdülhamit'e en yakın isimlerden mabeyn } \\
\text { müşiri Eğinli Sait Paşanın hatıratıdır. }\end{array}$ & Hatırat & 2 & 9 & 186-189 \\
\hline Eğinli Sait Paşa & Hatira & $\begin{array}{l}\text { II. Abdülhamit'e en yakın isimlerden mabeyn } \\
\text { müşiri Eğinli Sait Paşanın hatıratıdır. }\end{array}$ & Hatırat & 2 & 10 & $256-263$ \\
\hline Eğinli Sait Paşa & Hatıra & $\begin{array}{l}\text { II. Abdülhamit'e en yakın isimlerden mabeyn } \\
\text { müşiri Eğinli Sait Paşanın hatıratıdır. }\end{array}$ & Hatırat & 2 & 11 & $320-325$ \\
\hline Ĕ̆inli Sait Paşa & Hatira & $\begin{array}{l}\text { II. Abdülhamit'e en yakın isimlerden mabeyn } \\
\text { müşiri Eğinli Sait Paşanın hatıratıdır. }\end{array}$ & Hatırat & 2 & 12 & $362-366$ \\
\hline Eğinli Sait Paşa & Hatıra & $\begin{array}{l}\text { II. Abdülhamit'e en yakın isimlerden mabeyn } \\
\text { müşiri Eğinli Sait Paşanın hatıratıdır. }\end{array}$ & Hatırat & 3 & 13 & 414 \\
\hline Gıyas Sağer & Biyografi & $\begin{array}{l}\text { Osmanlı Ulemasından Mustafa Ahteri } \\
\text { Efendinin hayatı ve mezar taşında yazılanlar } \\
\text { izah edilmektedir. }\end{array}$ & Mustafa Ahteri Efendi & 2 & 8 & $110-112$ \\
\hline Hayrullah Efendi & $\begin{array}{l}\text { Tiyatro } \\
\text { Oyunu }\end{array}$ & $\begin{array}{l}\text { Fransa'da Şatle Tiyatrosunda oynanan } \\
\text { oyunlardan Rotomago'nun çevirisidir. }\end{array}$ & $\begin{array}{l}\text { Hamid'in Babası } \\
\text { Hayrullah Efendinin } \\
\text { Piyesi (Rotomago) }\end{array}$ & 1 & 2 & 109-122 \\
\hline Hayrullah Efendi & $\begin{array}{l}\text { Araştırma- } \\
\text { Inceleme }\end{array}$ & $\begin{array}{l}\text { Encümen-i Daniş Reisi olan (Abdülhak } \\
\text { Hamit'in babası) Hayrullah Efendinin Maarif } \\
\text { Islahına dair Bab-ı Aliye sunduğu mektubu ve } \\
\text { aldiğı cevaba ilişkin analizi yer almaktadır. }\end{array}$ & $\begin{array}{l}\text { "Encümen-i Daniş" } \\
\text { Reisinin Maarif } \\
\text { Islahına Ait Layihası }\end{array}$ & 2 & 8 & 102-104 \\
\hline Hayrullah Efendi & Hikaye & $\begin{array}{l}\text { Tanzimat döneminde Hayrullah Efendi } \\
\text { tarafindan kaleme alınmıştır. }\end{array}$ & $\begin{array}{l}\text { Hikaye-i İbrahim Paşa } \\
\text { be-İbrahim-i Gülşeni }\end{array}$ & 2 & 8 & $77-91$ \\
\hline Hoca Naum & $\begin{array}{l}\text { Tiyatro } \\
\text { Oyunu }\end{array}$ & $\begin{array}{l}\text { Naum Tiyatrosunda oynanmış bir oyunun } \\
\text { risalesidir. }\end{array}$ & Allahın Belası & 2 & 7 & $6-9$ \\
\hline
\end{tabular}




\begin{tabular}{|c|c|c|c|c|c|c|}
\hline $\begin{array}{l}\text { Hüseyin Namık } \\
\text { Orkun }\end{array}$ & $\begin{array}{l}\text { Araştırma- } \\
\text { Inceleme }\end{array}$ & $\begin{array}{l}\text { Kemçik Irmağının Cirgak mevkiinde } \\
\text { bulunan yazıtın transkripsiyonu ve tercümesi } \\
\text { yapılmıştır. }\end{array}$ & Kemçik-Cirgak yazıtı & 1 & 1 & $29-33$ \\
\hline $\begin{array}{l}\text { Hüseyin Namık } \\
\text { Orkun }\end{array}$ & $\begin{array}{l}\text { Araştırma- } \\
\text { Inceleme }\end{array}$ & $\begin{array}{l}\text { Anadolu Türk Beyliklerinin Haçlı bayrakları } \\
\text { hakkında yazılan makale münasebetiyle } \\
\text { Kumanların Arması hakkında yazılmıştır. }\end{array}$ & Kumanlarda Arma & 1 & 2 & $142-144$ \\
\hline $\begin{array}{l}\text { Hüseyin Namık } \\
\text { Orkun }\end{array}$ & Bibliyografya & $\begin{array}{l}\text { Yazan: Ahmet Cevat Emre- Türk Dil Kurumu, } \\
\text { Istanbul, } 1938\end{array}$ & $\begin{array}{l}\text { Türk Yazısının Menşei } \\
\text { (Bibliyografya) }\end{array}$ & 1 & 2 & $164-165$ \\
\hline $\begin{array}{l}\text { Hüseyin Namık } \\
\text { Orkun }\end{array}$ & $\begin{array}{l}\text { Araştırma- } \\
\text { Inceleme }\end{array}$ & $\begin{array}{l}\text { Yenisey havzasinda Uyug nehrine akan } \\
\text { bölgede yer alan yazıtın transkripsiyonu ve } \\
\text { tercümesi }\end{array}$ & Uyug-Turan Yazıtı & 1 & 3 & $224-226$ \\
\hline $\begin{array}{l}\text { Hüseyin Namık } \\
\text { Orkun }\end{array}$ & Bibliyografya & $\begin{array}{l}\text { Kitap tanitımı. Yazan: Osman Engin, İstanbul } \\
1939\end{array}$ & $\begin{array}{l}\text { Türkiye Maarif Tarihi } \\
\text { (Bibliyografya) }\end{array}$ & 1 & 3 & $247-248$ \\
\hline $\begin{array}{l}\text { Hüseyin Namık } \\
\text { Orkun }\end{array}$ & $\begin{array}{l}\text { Araştırma- } \\
\text { Inceleme }\end{array}$ & $\begin{array}{l}\text { Orhan Şaik Gökyay'a ve Dede Korkud eserine } \\
\text { eleştiriler }\end{array}$ & $\begin{array}{l}\text { Üçüncü Ders (Orhan } \\
\text { Şaik Gökyay'a) }\end{array}$ & 1 & 4 & 273-282 \\
\hline $\begin{array}{l}\text { Hüseyin Namık } \\
\text { Orkun }\end{array}$ & Eleştiri-Cevap & $\begin{array}{l}\text { Abdülkadir Inan'ın Oluş mecmuasında } \\
\text { Orhan Şaik Gökay'ı ve neşri Dede Korkud'u } \\
\text { müdafaa etmesi eleştirilmektedir. }\end{array}$ & Bir İah & 1 & 5 & 416 \\
\hline $\begin{array}{l}\text { Hüseyin Namık } \\
\text { Orkun }\end{array}$ & $\begin{array}{l}\text { Araştırma- } \\
\text { Inceleme }\end{array}$ & $\begin{array}{l}\text { İsmail Hami Danişmend'in Osmanlıların aslı } \\
\text { hakkında yazdıkları münasebetiyle kaleme } \\
\text { alınmıştır. Aynı konuda benzer görüşler } \\
\text { ortaya konulmaktadır. }\end{array}$ & $\begin{array}{l}\text { Osmanliların Aslina } \\
\text { Dair }\end{array}$ & 1 & 5 & $345-357$ \\
\hline $\begin{array}{l}\text { Hüseyin Namık } \\
\text { Orkun }\end{array}$ & Bibliyografya & $\begin{array}{l}\text { Şükrullah-ı Rumi'nin "Behcet-üt-teravih adlı } \\
\text { eserinin çevirisi Atsız, İstanbul,1939, tanıtımı }\end{array}$ & $\begin{array}{l}\text { Dokuz Boy Türkler Ve } \\
\text { Osmanlı Sultanları } \\
\text { Tarihi-Kırşehir Tarihi } \\
\text { (Bibliyografya) }\end{array}$ & 1 & 5 & $411-412$ \\
\hline $\begin{array}{l}\text { Hüseyin Namık } \\
\text { Orkun }\end{array}$ & $\begin{array}{l}\text { Araştırma- } \\
\text { Inceleme }\end{array}$ & $\begin{array}{l}\text { Yenisey nehri havzasında bulunan yazıt } \\
\text { ve hakkında yapılan neşirler üzerine bir } \\
\text { değerlendirme yapılmaktadır. }\end{array}$ & Yenisey Yazıtları & 1 & 6 & $438-446$ \\
\hline $\begin{array}{l}\text { Hüseyin Namık } \\
\text { Orkun }\end{array}$ & $\begin{array}{l}\text { Araştırma- } \\
\text { Inceleme }\end{array}$ & $\begin{array}{l}\text { Ali Ulvi Elöve'nin "Yaruk Tigin-Çakul } \\
\text { kitabesi" makalesi eleştiriliyor. }\end{array}$ & $\begin{array}{l}\text { Yaruk Tigin-Çakul } \\
\text { Makalesine Ait Bazı } \\
\text { Notlar }\end{array}$ & 1 & 6 & $470-471$ \\
\hline $\begin{array}{l}\text { Hüseyin Namık } \\
\text { Orkun }\end{array}$ & $\begin{array}{l}\text { Araştırma- } \\
\text { Inceleme }\end{array}$ & $\begin{array}{l}\text { Eski Türklerde kullanılan armalar hakkında } \\
\text { örnekler verilmiş, çifte başı kartal armasının } \\
\text { Türkün asırlarca kullandığı milli arması } \\
\text { olduğu ifade edilmiştir. }\end{array}$ & $\begin{array}{l}\text { Eski Türklerde Kartal } \\
\text { Arması }\end{array}$ & 2 & 7 & $29-34$ \\
\hline $\begin{array}{l}\text { Hüseyin Namık } \\
\text { Orkun }\end{array}$ & $\begin{array}{l}\text { Araştırma- } \\
\text { Inceleme }\end{array}$ & $\begin{array}{l}\text { Beynelmilel Arkeoloji Kongresinde irad } \\
\text { edilmek üzere hazırlanmış bir tezdir. Önce } \\
\text { tarih bilgisine sahip olmak daha sonra folklor } \\
\text { malzemesi toplamak gerekir, demektedir. }\end{array}$ & Tarih ve Folklor & 2 & 8 & $105-109$ \\
\hline $\begin{array}{l}\text { Hüseyin Namık } \\
\text { Orkun }\end{array}$ & $\begin{array}{l}\text { Araştırma- } \\
\text { Inceleme }\end{array}$ & $\begin{array}{l}\text { Barlık nehri çevresinde bulunan dört } \\
\text { kitabenin transkripsiyonu, tercümesi ve bazı } \\
\text { analizler yer almaktadır. }\end{array}$ & $\begin{array}{l}\text { Barık ve Begre } \\
\text { Kitabeleri }\end{array}$ & 2 & 9 & $157-161$ \\
\hline $\begin{array}{l}\text { Hüseyin Namık } \\
\text { Orkun }\end{array}$ & $\begin{array}{l}\text { Araştırma- } \\
\text { Inceleme }\end{array}$ & $\begin{array}{l}\text { Bizans Kaynaklarında geçen Oğuz tarihi } \\
\text { incelenmiştir. }\end{array}$ & $\begin{array}{l}\text { Bizans tarihlerine Göre } \\
\text { Oğuzlar }\end{array}$ & 3 & $\begin{array}{l}14- \\
15 \\
\end{array}$ & $431-437$ \\
\hline $\begin{array}{l}\text { Hüseyin Sadettin } \\
\text { Arel }\end{array}$ & $\begin{array}{l}\text { Araştırma- } \\
\text { Inceleme }\end{array}$ & $\begin{array}{l}\text { Yazılarını okumak zahmetinde bulunanların } \\
\text { Türk musikisine az çok vakıf olduklarını } \\
\text { kabul etmektedir. Türk musikisinin başka } \\
\text { bir milletten gelme sananların ona İranilik, } \\
\text { Araplık, Yunanlık, Bizanslılık isnad } \\
\text { etmeleri nedeniyle dört guruba ayrıldığını } \\
\text { söylemektedir. Tarihi bilgiler ışığında } \\
\text { Iranlıların bize musiki vermek şöyle dursun } \\
\text { bilakis bizden musiki aldığını kabul etmek } \\
\text { gerekir, diyor. }\end{array}$ & $\begin{array}{l}\text { Türk Musikisi } \\
\text { Kimindir? I, Iran } \\
\text { Musikisi-1 }\end{array}$ & 1 & 1 & $57-66$ \\
\hline
\end{tabular}




\begin{tabular}{|c|c|c|c|c|c|c|}
\hline $\begin{array}{l}\text { Hüseyin Sadettin } \\
\text { Arel }\end{array}$ & $\begin{array}{l}\text { Araştırma- } \\
\text { Inceleme }\end{array}$ & $\begin{array}{l}\text { Asırlarca süren Türk istilası Iran'da her ne } \\
\text { taksimatl olursa olsun eski musiki sistemini } \\
\text { yıkıp yok etmiş yerine kendi } 24 \text { taksimatl } \\
\text { sistemini koymuştur, diyor. }\end{array}$ & $\begin{array}{l}\text { Türk Musikisi } \\
\text { Kimindir? II, Iran } \\
\text { Musikisi-2 }\end{array}$ & 1 & 2 & $150-160$ \\
\hline $\begin{array}{l}\text { Hüseyin Sadettin } \\
\text { Arel }\end{array}$ & $\begin{array}{l}\text { Araştırma- } \\
\text { Inceleme }\end{array}$ & $\begin{array}{l}\text { Köşede bucakta Türk tesirinden uzak kalmış } \\
\text { bir Arap musikisi veya bundan bir kırıntı } \\
\text { bulabilir miyim diye çok emek sarf etmiştim, } \\
\text { diyor. }\end{array}$ & $\begin{array}{l}\text { Türk Musikisi } \\
\text { Kimindir? III, Arap } \\
\text { Musikisi-1 }\end{array}$ & 1 & 3 & $227-236$ \\
\hline $\begin{array}{l}\text { Hüseyin Sadettin } \\
\text { Arel }\end{array}$ & $\begin{array}{l}\text { Araştırma- } \\
\text { Inceleme }\end{array}$ & $\begin{array}{l}\text { "Araplar tarafından Türk musikisinin bizden } \\
\text { nasıl alındiğını, âdeta elleri cebimizde iken, } \\
\text { kendi gözlerinizle görmek ister misiniz?", diye } \\
\text { soruyor. }\end{array}$ & $\begin{array}{l}\text { Türk Musikisi } \\
\text { Kimindir? IV Arap } \\
\text { Musikisi-2 }\end{array}$ & 1 & 4 & $316-327$ \\
\hline $\begin{array}{l}\text { Hüseyin Sadettin } \\
\text { Arel }\end{array}$ & $\begin{array}{l}\text { Araştırma- } \\
\text { Inceleme }\end{array}$ & $\begin{array}{l}\text { Arap musikişinas Abdülaziz Tevfik’ten } \\
\text { aktardığına göre: "Kürdi, Bestenigar, } \\
\text { Hicazkar, Kürdi makamlarını aldık ve halis } \\
\text { Türk makamları olmalarına rağmen bunları } \\
\text { tıpkı Türkler gibi taganni ettik." }\end{array}$ & $\begin{array}{l}\text { Türk Musikisi } \\
\text { Kimindir? V, Arap } \\
\text { Musikisi-3 }\end{array}$ & 1 & 5 & $383-397$ \\
\hline $\begin{array}{l}\text { Hüseyin Sadettin } \\
\text { Arel }\end{array}$ & $\begin{array}{l}\text { Araştırma- } \\
\text { Inceleme }\end{array}$ & $\begin{array}{l}\text { Musikimizin İsmail Paşa zamanında } \\
\text { Mısır'a gidişi onun ilk yolculuğu değildir. } \\
\text { Asırlarca evvel Mısır'da musikimiz yerleşmiş; } \\
\text { fakat Arapların elinde ve dilinde bozula- } \\
\text { bozula, darala-darala, küçüle-küçüle adeta } \\
\text { soysuzlaşmıştı, diyor. }\end{array}$ & $\begin{array}{l}\text { Türk Musikisi } \\
\text { Kimindir? VI, Arap } \\
\text { Musikisi-4 }\end{array}$ & 1 & 6 & $452-469$ \\
\hline $\begin{array}{l}\text { Hüseyin Sadettin } \\
\text { Arel }\end{array}$ & $\begin{array}{l}\text { Araştırma- } \\
\text { Inceleme }\end{array}$ & $\begin{array}{l}\text { Eski Yunan musikisine ilişkin makam ve } \\
\text { perdeler anlatılmaktadır. }\end{array}$ & $\begin{array}{l}\text { Türk Musikisi } \\
\text { Kimindir? IX, Eski } \\
\text { Yunan Musikisi-3 }\end{array}$ & 2 & 9 & $162-173$ \\
\hline $\begin{array}{l}\text { Hüseyin Sadettin } \\
\text { Arel }\end{array}$ & $\begin{array}{l}\text { Araştırma- } \\
\text { Inceleme }\end{array}$ & $\begin{array}{l}\text { İran ve Rap musikisinin nihayet bizim } \\
\text { musikimizden ibaret olduğu için Türk } \\
\text { musikisini az çok bilenlere karşı teknik } \\
\text { izahatlara gerek kalmıyordu diyor. Ancak } \\
\text { Eski Yunan musikisinden bahsederken teknik } \\
\text { konulara girmesi gerektiğini anlatıyor. }\end{array}$ & $\begin{array}{l}\text { Türk Musikisi } \\
\text { Kimindir? VII, Eski } \\
\text { Yunan Musikisi-1 }\end{array}$ & 2 & 7 & $45-59$ \\
\hline $\begin{array}{l}\text { Hüseyin Sadettin } \\
\text { Arel }\end{array}$ & $\begin{array}{l}\text { Araştırma- } \\
\text { Inceleme }\end{array}$ & $\begin{array}{l}\text { Eflatun'a göre Yunan musikisinde tek bir } \\
\text { makam vardır o da Doristi'den ibarettir. }\end{array}$ & $\begin{array}{l}\text { Türk Musikisi } \\
\text { Kimindir? VIII, Eski } \\
\text { Yunan Musikisi-2 } \\
\end{array}$ & 2 & 8 & $113-125$ \\
\hline $\begin{array}{l}\text { Hüseyin Sadettin } \\
\text { Arel }\end{array}$ & $\begin{array}{l}\text { Araştırma- } \\
\text { Inceleme }\end{array}$ & $\begin{array}{l}\text { Doristi makamı ve duraklarına ilişkin etütler } \\
\text { yer alıyor }\end{array}$ & $\begin{array}{l}\text { Türk Musikisi } \\
\text { Kimindir? X, Eski } \\
\text { Yunan Musikisi-4 }\end{array}$ & 2 & 10 & 241-255 \\
\hline $\begin{array}{l}\text { Hüseyin Sadettin } \\
\text { Arel }\end{array}$ & $\begin{array}{l}\text { Araştırma- } \\
\text { Inceleme }\end{array}$ & $\begin{array}{l}\text { Eski Yunan musikisinin mahiyetini gören } \\
\text { okuyucular, Türk musikisi ile arasındaki } \\
\text { yabancılı̆̆ı teşhis etmiş olacaktır, diyor. }\end{array}$ & $\begin{array}{l}\text { Türk Musikisi } \\
\text { Kimindir? XI, Eski } \\
\text { Yunan Musikisi-5 }\end{array}$ & 2 & 11 & $298-313$ \\
\hline $\begin{array}{l}\text { Hüseyin Sadettin } \\
\text { Arel }\end{array}$ & $\begin{array}{l}\text { Araştırma- } \\
\text { Inceleme }\end{array}$ & $\begin{array}{l}\text { Acemlerden, Araplardan, Yunanlardan } \\
\text { musiki almamış olduğumuzu şimdiye kadar } \\
\text { yaptığımız tetkikat bize gösterdi. Kala Kala } \\
\text { Bizanslılar kalıyor diyor. Çetrefilli olarak söz } \\
\text { ettiği Bizans musikisinin mahiyeti hakkında } \\
\text { bilgi veriyor. }\end{array}$ & $\begin{array}{l}\text { Türk Musikisi } \\
\text { Kimindir? XII, Bizans } \\
\text { Musikisi-1 }\end{array}$ & 2 & 12 & $340-356$ \\
\hline $\begin{array}{l}\text { Hüseyin Sadettin } \\
\text { Arel }\end{array}$ & $\begin{array}{l}\text { Araştırma- } \\
\text { Inceleme }\end{array}$ & $\begin{array}{l}\text { Bizans musikisine dair İstanbul'daki } \\
\text { mütehassısın söylediklerini olduğu gibi } \\
\text { aktarmaktadır. }\end{array}$ & $\begin{array}{l}\text { Türk Musikisi Kimdir? } \\
\text { XIII Bizans Musikisi-2 }\end{array}$ & 3 & 13 & $401-413$ \\
\hline
\end{tabular}




\begin{tabular}{|c|c|c|c|c|c|c|}
\hline $\begin{array}{l}\text { Hüseyin Sadettin } \\
\text { Arel }\end{array}$ & $\begin{array}{l}\text { Araşttrma- } \\
\text { Inceleme }\end{array}$ & $\begin{array}{l}\text { Bizans müelliflerinden, Bizans nota } \\
\text { yazısından, Bizans makam ve usullerinden ve } \\
\text { Bizans musiki parçalarından teknik anlamda } \\
\text { bahsederek Türk musikisiyle arasındaki } \\
\text { fakları anlamak için fikir veriyor. Ben } \\
\text { bestekârlardan şu sıfatları isterim diyerek } \\
\text { sıralıyor: (1) Doğuştan musikiye istidatlı } \\
\text { olmak, (2) En az yüksek tahsilini bitirmiş } \\
\text { olmak ve bununla kalmayarak umumi } \\
\text { kültürünü gelisstirmek (3) Türk Musikisini } \\
\text { ve Garp musikisini her ikisinde bestekârlık } \\
\text { yapabilecek kadar iyi bilmek, (4) Musikiden } \\
\text { başka bir meslekle uğraşmamak }\end{array}$ & $\begin{array}{l}\text { Türk Musikisi } \\
\text { Kimindir? XIV Bizans } \\
\text { Musikisi-3, Son Söz }\end{array}$ & 3 & $\begin{array}{l}14- \\
15\end{array}$ & $445-472$ \\
\hline İsmail Habib & $\begin{array}{l}\text { Araştırma- } \\
\text { Inceleme }\end{array}$ & $\begin{array}{l}\text { "Namık Kemal, üç çeyrek asır önce "Tasvir-i } \\
\text { Efkar"da açıtan sade Türkçeyi müdafaa } \\
\text { ediyordu. Kendisi neye öyle yazmadı. Çünkü } \\
\text { o zaman kimse onu edip diye okumazdı", } \\
\text { diyor ve ekliyor "Güzel Türkçe: sana uzun } \\
\text { asırlar içinde çetin yollardan dolaşarak } \\
\text { kavuştuk. Geç kalışımızı sevgimizin } \\
\text { coşkunluğuyla ödüyoruz." }\end{array}$ & $\begin{array}{l}\text { Eski Nesirde Saf Türkçe } \\
\text { ve Divan Edebiyatında } \\
\text { Nesirsizlik }\end{array}$ & 1 & 1 & $34-38$ \\
\hline $\begin{array}{l}\text { İsmail Hami } \\
\text { Danişmend } \\
\text { (İ.H.D) }\end{array}$ & Bibliyografya & $\begin{array}{l}\text { Türk Dil Kurumu'nun } 1940 \text { yılında neşre } \\
\text { başladığı "Türkiye'de halk ağzından söz } \\
\text { derleme dergisi" tanıtılmaktadır." Türk dili } \\
\text { Ingilizce, Fransızca ve Almanca gibi Avrupa } \\
\text { dillerinin hepsinden daha zengindi. }\end{array}$ & $\begin{array}{l}\text { Türk Diline Ait Yeni } \\
\text { Bir Abide: Söz Derleme } \\
\text { Dergisi (Bibliyografya) }\end{array}$ & 3 & $\begin{array}{l}14- \\
15\end{array}$ & $484-487$ \\
\hline $\begin{array}{l}\text { İsmail Hami } \\
\text { Danişmend }\end{array}$ & Eleştiri-Cevap & $\begin{array}{l}\text { "İlmi, edebi ve içtimai" olarak bilinen bir } \\
\text { mecmuada çıkan "Türklük Mecmuasında bir } \\
\text { yazı" başlıkl tenkitte yer an iddialara cevap } \\
\text { veriyor. "Eski Şark ve yeni Garp telakkilerine } \\
\text { göre ırk nedir" başlıklı makale hakkında. }\end{array}$ & Bir Zihniyet Hastalığı & 1 & 4 & $283-295$ \\
\hline $\begin{array}{l}\text { İsmail Hami } \\
\text { Danişmend }\end{array}$ & $\begin{array}{l}\text { Arassttrma- } \\
\text { Inceleme }\end{array}$ & $\begin{array}{l}\text { Irkı şöyle tanımlıyor: Irk, antropolojik ve } \\
\text { zoolojik bir mevhumdur; fakat milliyet yani } \\
\text { tali ırk mevhumunda aranan ilk şey vatan } \\
\text { yani coğrafi müessir alandır. Çünkü herhangi } \\
\text { bir cemaate ırki şahsiyetinin yanında milli bir } \\
\text { şahsiyette verip onu bir milliyet haline getiren } \\
\text { ilk amil, tabiat yani muayyen bir memlekettir. } \\
\text { En kuvvetli milletler, orki şahsiyetle milli } \\
\text { şahsiyeti cem eden cemiyetlerdir. }\end{array}$ & $\begin{array}{l}\text { Eski Şark ve Yeni Garp } \\
\text { Telakkilerine Göre: Irk } \\
\text { Nedir? }\end{array}$ & 1 & 1 & $39-57$ \\
\hline $\begin{array}{l}\text { İsmail Hami } \\
\text { Danişmend }\end{array}$ & $\begin{array}{l}\text { Arassttrma- } \\
\text { Inceleme }\end{array}$ & $\begin{array}{l}\text { Bu Vakayiname Anadolu Türk tarihinin } \\
\text { ilk devirlerine ait kaynakların belki en } \\
\text { mühimidir, diyor. Eserin Anadolu Türklüğ̈̈ne } \\
\text { dair kısımları verilerek mukayeseli bir } \\
\text { tercümeye tutulmuştur. }\end{array}$ & $\begin{array}{l}\text { Süryani Mikail } \\
\text { Vakayinamesi I, }\end{array}$ & 1 & 1 & $70-80$ \\
\hline $\begin{array}{l}\text { İsmail Hami } \\
\text { Danişmend }\end{array}$ & $\begin{array}{l}\text { Arasstırma- } \\
\text { Inceleme }\end{array}$ & $\begin{array}{l}\text { Bu Vakayiname Anadolu Türk tarihinin } \\
\text { ilk devirlerine ait kaynakların belki en } \\
\text { mühimidir, diyor. Eserin Anadolu Türklüğ̈̈ne } \\
\text { dair kısımları verilerek mukayeseli bir } \\
\text { tercümeye tutulmustur. }\end{array}$ & $\begin{array}{l}\text { Süryani Mikail } \\
\text { Vakayinamesi II, }\end{array}$ & 1 & 2 & $161-163$ \\
\hline
\end{tabular}




\begin{tabular}{lll}
\hline İsmail Hami & Araştırma- & Misır Kölemen devrinde Cemaliddün ebu- \\
Danişmend & İnceleme & Mohammed Abdullah-it-Türki'nin yazdiğı, \\
& "Kitab-u Bulgat-il Muştak fi Luğat-it Türk-i \\
& ve-l-Kıfcak" (Kaşgarlı Mahmut'un eseri gibi \\
& daha çok küçük ölçekli bir Türkçe Lügati \\
& denebilir) Zajaczkowski "Manuel arabe de la \\
& langue des Turcs et des Kiptchs" Varşova-1938 \\
& (Arapça-Türkçe Lügat) \\
\hline
\end{tabular}

\begin{tabular}{lll}
\hline İsmail Hami & Biyografi & Vani Mehmed Efendi'nin hayatı, düşünceleri \\
Danişmend & ve çalışmaları anlatılmaktadır.
\end{tabular}

Bulğat-ül-Muştak

(Bibliyografya)

$\begin{array}{llll}\text { Arap ve Türk } & 1 & 2 & 122-142 \\ \text { Kültürlerinin Mücadele } & & & \\ \begin{array}{l}\text { Tarihinden: XVII nci } \\ \text { Asırda Bir Türk Irkçısı }\end{array} & & & \\ \begin{array}{l}\text { Osmanlıların Aslı } \\ \text { Meselesi: I, Osman }\end{array} & 1 & 3 & 207-223\end{array}$

Meselesi: I, Osman

Gazi'nin Nesep ve

Hüviyeti halidir. Osman Gazi'nin babası Ertuğrul isminde bir gemici ve bilhassa bir korsandir. Ertuğrulun babasının kim olduğu neçhuldür, Süleymanş ibni Kayaalp ibni Kızılboğa nesebi uydurmadır. Osman'ın kendisi de denizcidir. Osmanlı karada değil denizde doğmuştur.

\begin{tabular}{lll}
\hline İsmail Hami & Araştırma- & Osmanoğullarına isnad edilen Arap,Acem, \\
Danişmend & İnceleme & Rum, Moğolluk ve Tatarlık iddialaına ilişkin \\
& & açıklamalar yer almaktadır.
\end{tabular}

\begin{tabular}{ll}
\hline İsmail Hami & Araştırma- \\
Danişmend & İnceleme
\end{tabular}

Bu Vakayiname Anadolu Türk tarihinin ilk devirlerine ait kaynaklarm belki en mühimidir, diyor. Eserin Anadolu Türklüğ̈̈ne dair kısımları verilerek mukayeseli bir tercümeye tutulmuştur.

\begin{tabular}{|c|c|c|c|c|c|c|}
\hline $\begin{array}{l}\text { İsmail Hami } \\
\text { Danişmend }\end{array}$ & Eleștiri-Cevap & $\begin{array}{l}\text { Osman Gazinin nesep ve hüviyeti başlıklı } \\
\text { makaleye, } 22 \text { Temmuz } 1939 \text { tarihli } \\
\text { Cumhuriyet Gazetesinde Feridun Nafiz'in } \\
\text { "Fatih'n nesebi" ismiyle yazdığı eleştireye } \\
\text { ilişkin cevaplar vardır. }\end{array}$ & $\begin{array}{l}\text { Yanlış Çıkaranların } \\
\text { Yanlışları }\end{array}$ & 1 & 5 & $413-415$ \\
\hline $\begin{array}{l}\text { İsmail Hami } \\
\text { Danişmend }\end{array}$ & $\begin{array}{l}\text { Araştırma- } \\
\text { Inceleme }\end{array}$ & $\begin{array}{l}\text { Osman Gazi'ye izafe edilen "Rumluk" } \\
\text { isnadına ilişikin açılklamalar yer almaktadır. }\end{array}$ & $\begin{array}{l}\text { Osmanliların } \\
\text { Aslı Meselesi: III, } \\
\text { Osmanoğullarına } \\
\text { İsnad Edilen Sahte } \\
\text { Milliyetler }\end{array}$ & 1 & 6 & $425-437$ \\
\hline $\begin{array}{l}\text { İsmail Hami } \\
\text { Danişmend }\end{array}$ & Eleştiri-Cevap & $\begin{array}{l}\text { Yeni Türk Mecmuasının Ağustos } 1939 \\
\text { tarihli ve } 80 \text { numaralı nüshası 330-336'ıncı } \\
\text { sayfalarında "Tahlil ve Tenkit: Osman } \\
\text { Gazinin nesep ve hüviyeti" (Adnan Erzi) } \\
\text { isimli makalede yapılan tenkide cevaptır. }\end{array}$ & $\begin{array}{l}\text { "Osman Gazi'nin } \\
\text { Nesep Ve Hüviyeti" } \\
\text { Hakkındaki Tenkide } \\
\text { Cevap }\end{array}$ & 1 & 6 & $477-489$ \\
\hline $\begin{array}{l}\text { İsmail Hami } \\
\text { Danişmend }\end{array}$ & $\begin{array}{l}\text { Araştırma- } \\
\text { Inceleme }\end{array}$ & $\begin{array}{l}\text { Bu Vakayiname Anadolu Türk tarihinin } \\
\text { ilk devirlerine ait kaynakların belki en } \\
\text { mühimidir, diyor. Eserin Anadolu Türklügüne } \\
\text { dair kısımları verilerek mukayeseli bir } \\
\text { tercümeye tutulmuştur. }\end{array}$ & $\begin{array}{l}\text { Süryani Mikail } \\
\text { Vakayinamesi IV, }\end{array}$ & 1 & 5 & $407-410$ \\
\hline $\begin{array}{l}\text { İsmail Hami } \\
\text { Danişmend }\end{array}$ & $\begin{array}{l}\text { Araştırma- } \\
\text { Inceleme }\end{array}$ & $\begin{array}{l}\text { Bu Vakayiname Anadolu Türk tarihinin } \\
\text { ilk devirlerine ait kaynakların belki en } \\
\text { mühimidir, diyor. Eserin Anadolu Türklüğüne } \\
\text { dair kısımları verilerek mukayeseli bir } \\
\text { tercümeye tutulmuștur. }\end{array}$ & $\begin{array}{l}\text { Süryani Mikail } \\
\text { Vakayinamesi V, }\end{array}$ & 1 & 6 & 490 \\
\hline
\end{tabular}

Osmanlilarin $\quad 1 \quad 567$ 367-382

Aslı Meselesi: II,

Osmanoğullarına

İsnad Edilen Sahte Milliyetler

$\begin{array}{llll}\text { Süryani Mikail } & 1 & 3 & \text { 244-246 }\end{array}$
Vakayinamesi III, 


\begin{tabular}{|c|c|c|c|c|c|c|}
\hline $\begin{array}{l}\text { İsmail Hami } \\
\text { Danişmend }\end{array}$ & $\begin{array}{l}\text { Araştırma- } \\
\text { Inceleme }\end{array}$ & $\begin{array}{l}\text { Bu Vakayiname Anadolu Türk tarihinin } \\
\text { ilk devirlerine ait kaynakların belki en } \\
\text { mühimidir, diyor. Eserin Anadolu Türklüğ̈̈ne } \\
\text { dair kısımları verilerek mukayeseli bir } \\
\text { tercümeye tutulmuştur. }\end{array}$ & $\begin{array}{l}\text { Süryani Mikail } \\
\text { Vakayinamesi }\end{array}$ & 2 & 9 & \\
\hline $\begin{array}{l}\text { İsmail Hami } \\
\text { Danişmend }\end{array}$ & $\begin{array}{l}\text { Araştırma- } \\
\text { Inceleme }\end{array}$ & $\begin{array}{l}\text { Bu Vakayiname Anadolu Türk tarihinin } \\
\text { ilk devirlerine ait kaynakların belki en } \\
\text { mühimidir, diyor. Eserin Anadolu Türklüğ̈̈ne } \\
\text { dair kısımları verilerek mukayeseli bir } \\
\text { tercümeye tutulmuştur. }\end{array}$ & $\begin{array}{l}\text { Süryani Mikail } \\
\text { Vakayinamesi }\end{array}$ & 2 & 10 & $264-267$ \\
\hline $\begin{array}{l}\text { İsmail Hami } \\
\text { Danişmend }\end{array}$ & $\begin{array}{l}\text { Araştırma- } \\
\text { Inceleme }\end{array}$ & $\begin{array}{l}\text { Bu Vakayiname Anadolu Türk tarihinin } \\
\text { ilk devirlerine ait kaynakların belki en } \\
\text { mühimidir, diyor. Eserin Anadolu Türklüğ̈̈ne } \\
\text { dair kısımları verilerek mukayeseli bir } \\
\text { tercümeye tutulmuştur. }\end{array}$ & $\begin{array}{l}\text { Süryani Mikail } \\
\text { Vakayinamesi }\end{array}$ & 2 & 12 & $369-372$ \\
\hline $\begin{array}{l}\text { İsmail Hami } \\
\text { Danişmend }\end{array}$ & $\begin{array}{l}\text { Araştırma- } \\
\text { Inceleme }\end{array}$ & $\begin{array}{l}\text { Osmanoğullarına isnad edilen Arap, Acem, } \\
\text { Rum, Moğolluk ve Tatarlık iddialarına ilişkin } \\
\text { açıklamalar yer almaktadır. Osmanoğulları } \\
\text { halis Türk'tür. }\end{array}$ & $\begin{array}{l}\text { Osman Oğullarına } \\
\text { İsnad Edilen Sahte } \\
\text { Milliyetler, IV }\end{array}$ & 2 & 7 & $10-19$ \\
\hline $\begin{array}{l}\text { İsmail Hami } \\
\text { Danişmend }\end{array}$ & $\begin{array}{l}\text { Araştırma- } \\
\text { Inceleme }\end{array}$ & $\begin{array}{l}\text { Hayrullah Efendinin kaleme aldiğı "Hikaye-i } \\
\text { İbrahim Paşa be-İbrahim-i Gülş̧eni'nin } \\
\text { yazılma sürecine ilişkin bilgiler veriyor. }\end{array}$ & $\begin{array}{l}\text { Türk Tiyatrosunun İlk } \\
\text { Piyesi }\end{array}$ & 2 & 8 & $73-76$ \\
\hline $\begin{array}{l}\text { İsmail Hami } \\
\text { Danişmend }\end{array}$ & 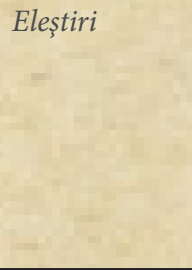 & $\begin{array}{l}\text { Türklüğ̈̈ Avrupa'nın ve dünyanın nazarında } \\
\text { aşağı görülen sarı Mongoloid mevkiden } \\
\text { çıarmak ve beyaz ırktan olduğumuzu } \\
\text { göstermek için kültür faaliyetlerinin } \\
\text { yapılması, dünya kültür ve medeniyet } \\
\text { tarihinde Türkün oynadığı rolün anlatılması } \\
\text { talebi yer alıyor. }\end{array}$ & $\begin{array}{l}\text { Maarif Vekiline Açık } \\
\text { Mektup }\end{array}$ & 2 & 9 & $145-152$ \\
\hline $\begin{array}{l}\text { İsmail Hami } \\
\text { Danişmend }\end{array}$ & $\begin{array}{l}\text { Araştırma- } \\
\text { Inceleme }\end{array}$ & $\begin{array}{l}\text { Ki-en-gin ismini Sümer ülkesi, Sümer şeklini } \\
\text { de millet olarak kullanmak gerektiğine iliş̧in } \\
\text { açıklamalar yer almaktadır. }\end{array}$ & Sümerlilerin İsmi & 2 & 9 & 193-207 \\
\hline $\begin{array}{l}\text { İsmail Hami } \\
\text { Danişmend }\end{array}$ & $\begin{array}{l}\text { Araştırma- } \\
\text { Inceleme }\end{array}$ & $\begin{array}{l}\text { Sümer milliyetinin Orta-Asya'dan gelmiş } \\
\text { muhtelif Türk dalgalarının halitası (bileşimi) } \\
\text { olduğuna iliş̧kin açıklamalar yer almaktadır. }\end{array}$ & Sümerlilerin Irkı & 2 & 10 & 209-222 \\
\hline $\begin{array}{l}\text { İsmail Hami } \\
\text { Danişmend }\end{array}$ & $\begin{array}{l}\text { Araştırma- } \\
\text { Inceleme }\end{array}$ & $\begin{array}{l}\text { Yazar Bursa'da gördü̈̆̈̈̈ Bursacılığı } \\
\text { açıklamaktadır. }\end{array}$ & Bursalıların Bursacılı̆̆ & 2 & 10 & $229-240$ \\
\hline $\begin{array}{l}\text { İsmail Hami } \\
\text { Danişmend }\end{array}$ & Bibliyografya & $\begin{array}{l}\text { Dr. Sadi Irmak'ın Tip Dünyası neşriyatı } \\
\text { no 11-115, İstanbul } 1937 \text { sayılı makalesi } \\
\text { tanıtılmaktadır. }\end{array}$ & $\begin{array}{l}\text { Anadolu Yörüklerinin } \\
\text { Kan Gruplarına } \\
\text { Dair Araştırmalar } \\
\text { (Bibliyografya) }\end{array}$ & 2 & 10 & $268-272$ \\
\hline $\begin{array}{l}\text { İsmail Hami } \\
\text { Danişmend }\end{array}$ & Biyografi & $\begin{array}{l}\text { İsmail Saib Efendinin hayatına ilişkin bilgiler } \\
\text { yer almaktadır. }\end{array}$ & İsmail Saib Efendi & 2 & 12 & $327-331$ \\
\hline $\begin{array}{l}\text { İsmail Hami } \\
\text { Danişmend }\end{array}$ & Biyografi & $\begin{array}{l}\text { Abdülhak Hamid'in hayatına ilişkin bilgiler } \\
\text { yer almaktadır. }\end{array}$ & $\begin{array}{l}\text { Abdülhak Hamid'e Ait } \\
\text { Hatıralar }\end{array}$ & 3 & 13 & $375-384$ \\
\hline $\begin{array}{l}\text { İsmail Hami } \\
\text { Danişmend }\end{array}$ & $\begin{array}{l}\text { Araştırma- } \\
\text { Inceleme }\end{array}$ & $\begin{array}{l}\text { Ali Süha Delibaş'in Moliere tercüme serisi } \\
\text { izah edilmektedir. }\end{array}$ & Mühim Bir Tercüme & 3 & $\begin{array}{l}14- \\
15\end{array}$ & $423-430$ \\
\hline J.H Mordtman & $\begin{array}{l}\text { Araştırma- } \\
\text { Inceleme }\end{array}$ & $\begin{array}{l}\text { J.H Mordtman'ın İslam Ansiklopedisinde yer } \\
\text { alan "Danişmendiyye maddesi aynen tercüme } \\
\text { ve neşredilmiştir }\end{array}$ & Melik Gazi Türbesi & 2 & 12 & $357-361$ \\
\hline Jean Deny & $\begin{array}{l}\text { Araştırma- } \\
\text { Inceleme }\end{array}$ & $\begin{array}{l}\text { "Takriben üç çeyrek asırdır Türk edebiyatı } \\
\text { bizim edebiyatın tesiri altında bulunmakla } \\
\text { beraber, ilk önce bizim edebiyatımız } \\
\text { Türkiye'nin tesiri altında kalmıştır." diyor. }\end{array}$ & $\begin{array}{l}\text { Fransa ile Türkiye } \\
\text { Arasında Edebi } \\
\text { Mübadeleler }\end{array}$ & 2 & 9 & $153-156$ \\
\hline
\end{tabular}




\begin{tabular}{ll}
\hline M. Şakir Ülkütaşır & Eleștiri- \\
& Bibliyografya
\end{tabular}

Dede Korkud'un Orhan Şaik Gökyay neşri üzerine tenkidi vardır. Hatalı kelimeler kullandığından bahisle Anadolu lehçeleri ve lügatına bakması gerekirdi, diyor

\begin{tabular}{ll}
\hline M. Şakir Ülkütaşır & Eleştiri- \\
& Bibliyografya
\end{tabular}

Dede Korkud'un Orhan Şaik Gökyay neşri üzerine tenkidi vardır. Hatalı kelimeler kullandığından bahsediyor.

\begin{tabular}{|c|c|c|}
\hline $\begin{array}{l}\text { Mahmut Ragip } \\
\text { Kösemihal }\end{array}$ & Eleştiri & $\begin{array}{l}\text { Nazan Danişmend'in Haçl Türk Bayrakları } \\
\text { makalesine cevap mahiyetindedir. }\end{array}$ \\
\hline
\end{tabular}

\begin{tabular}{ll}
\hline Naci Kum & Biyografi \\
\hline Naci Kum & $\begin{array}{l}\text { Araştırma- } \\
\text { Inceleme }\end{array}$ \\
\hline Nazan Danişmend & $\begin{array}{l}\text { Araştırma- } \\
\text { Inceleme }\end{array}$
\end{tabular}

Bursalı Ünlü bir pehlivan olan Demircili Softa Oğlu Mehmet Pehlivanın hayatı anlatılmaktadir.

Yazar Bursa Muradiye inceleme yaparken rastladiğı bir mezar taşının tercümesini yapmakta ve Alanya beyi Savcı bey oğlu Lütfi hakkında bilgiler vermektedir.

1305 yılında İspanyada doğan bir papaz İspanya'dan Çin'e kadar tüm dünyayı gezer, bir seyahatname yazar. Bu seyahatnamede bayraktan başka bir şeyden söz etmez. Gittiği her yerde bayrakları renkleriyle birlikte tespit ediyor. Bunları ilk defa1877'de Don Marcos Jimenes de la Espada isimli bir Ispanyol müellif "Libro del Conscimiento" adiyla kitap olarak yayınliyor. Daha sonra Ingiliz Sir Clements Markham bu kitabı Ingilizceye çevirip "Book of the Knowledge" ismiyle Londra'da bastıriyor (1912) Nazan Danişmend'in kaynak olarak kullandiğı bu kitaptır.

\begin{tabular}{|c|c|c|c|c|c|c|}
\hline Nazan Danişmend & Biyografi & $\begin{array}{l}\text { Abdülhak Hamit'in ölümünün üçüncü yılı } \\
\text { dolayısıyla kaleme alınmıştır. Hamit'in aile } \\
\text { bilgileri, aile bireylerinin fotoğrafları ile şiirleri } \\
\text { ve mektupları yer alıyor. }\end{array}$ & $\begin{array}{l}\text { Bir Zeybek Ailesinin } \\
\text { Irsiyet Tarihinden: } \\
\text { Abdülhak Hamit'de Şiir } \\
\text { Atavizmi }\end{array}$ & 1 & 2 & $81-98$ \\
\hline Nazan Danişmend & $\begin{array}{l}\text { Araştırma- } \\
\text { Inceleme }\end{array}$ & $\begin{array}{l}\text { Nazan Danişmend'e göre Bir zamanlar } \\
\text { Türkün kahramanlı̆ı maddeten, güzelliği de } \\
\text { manen yeryüzüne hakimdi: Eski Türklerin } \\
\text { dünyayı istilası demek, güzellerin çirkinlere, } \\
\text { güzelliğin çirkinliğe hakimiyeti demekti. } \\
\text { Türklerin vesikalarla ispat edilen güzelliğine } \\
\text { ilişkin bir konferansın metnidir. }\end{array}$ & $\begin{array}{l}\text { Tarih ve Edebiyatta: } \\
\text { Türk Güzelliği }\end{array}$ & 1 & 3 & $169-184$ \\
\hline Nazan Danişmend & Biyografi & $\begin{array}{l}\text { Nazan Danişmend dedesi olan 2. Abdülhamit } \\
\text { Dönemi mabeyn müşiri ve bahriye nazırı } \\
\text { Eğinli Sait Paşanın hayatını kaleme almış, } \\
\text { fotoğraflarına yer vermiştir. }\end{array}$ & $\begin{array}{l}\text { Türk Demokrasi } \\
\text { Tarihinin Unutulmuş } \\
\text { Simalarından: Eğinli } \\
\text { Sait Paşa }\end{array}$ & 1 & 4 & $249-261$ \\
\hline Nazan Danişmend & $\begin{array}{l}\text { Araştırma- } \\
\text { Inceleme }\end{array}$ & $\begin{array}{l}\text { Ĕ̈inli Sait Paşa Hatıratıyla ilgili Maarif } \\
\text { Müşteşarı Sayın Bay İhsan'dan bir fikra } \\
\text { nakledilmektedir. }\end{array}$ & $\begin{array}{l}\text { Abdülhamid'in } \\
\text { "Cemi'iyyet- } i \\
\text { Ebebiyye"si }\end{array}$ & 1 & 5 & 398-399 \\
\hline Nazan Danişmend & $\begin{array}{l}\text { Araştırma- } \\
\text { Inceleme }\end{array}$ & $\begin{array}{l}\text { Abdülhak Hamid şiiri hakkında } \\
\text { değerlendirmeler yer almaktadır. }\end{array}$ & $\begin{array}{l}\text { Şiirle Nesir Arasında } \\
\text { Üçüncü Bir İfade } \\
\text { Nev'i: "Nesr-i Mukaffa" }\end{array}$ & 3 & 13 & $385-388$ \\
\hline Nazım Yücelt & $\begin{array}{l}\text { Araştırma- } \\
\text { Inceleme }\end{array}$ & $\begin{array}{l}\text { Bursa'nın tarihi hakkında bilgiler } \\
\text { verilmektedir. }\end{array}$ & Tarihte Bursa & 2 & 11 & $273-276$ \\
\hline
\end{tabular}

Dede Korkud'un Orhan 14 330-336

Şaik Gökyay Neşri

Üzerine Tenkidi Notlar

(Bibliyografya), I,

Dede Korkud'un Orhan 116 491-496

Şaik Gökyay Neşri

Üzerine Tenkidi Notlar

(Bibliyografya), II,

$\begin{array}{llll}\text { Anketimize Cevap: } & 1 & 3 & 237-240\end{array}$

Haçlı Türk Bayrakları

Meselesi

Demircili Softa Oğlu $2211 \quad 282-285$

Mehmet Pehlivan

$\begin{array}{llll}\text { Alanya Beyi Savcı } & 3 & 14- & 438-440 \\ \text { Bey Oğlu Lütfi Beyin } & & 15 & \end{array}$

Mezartaşı

XIV üncü Asra Ait Bir $1 \quad 12$ 12-22

İspanyol Vesikasına

Göre: Anadolu Türk

Beyliklerinin Haçlı

Bayrakları 


\begin{tabular}{|c|c|c|c|c|c|c|}
\hline Nureddin Ardıç & $\begin{array}{l}\text { Araştırma- } \\
\text { Inceleme }\end{array}$ & $\begin{array}{l}\text { Tarih muallimlerinden Nureddin Ardıç } \\
\text { Harput'a giderek oranın tetkik olunmamış } \\
\text { kitabeleri üzerinde çalışmıştır. Arap baba } \\
\text { Mescidinde bulunan kitabenin mukayeseli } \\
\text { tercümesi yapılmaktadır. }\end{array}$ & $\begin{array}{l}\text { Harput'da Selçukilerin } \\
\text { Son Devirlerine Ait Bir } \\
\text { Kitabe }\end{array}$ & 1 & 6 & $447-451$ \\
\hline $\begin{array}{l}\text { Osman Nuri } \\
\text { Sumer }\end{array}$ & Eleştiri & $\begin{array}{l}\text { Nazan Danişmend'in Haçlı Türk Bayrakları } \\
\text { makalesine cevap mahiyetindedir. }\end{array}$ & $\begin{array}{l}\text { "Anadolu Türk } \\
\text { Beyliklerinin Haçlı } \\
\text { Bayrakları" Hakkında }\end{array}$ & 1 & 5 & $404-406$ \\
\hline Osman Turan & $\begin{array}{l}\text { Araştırma- } \\
\text { Inceleme }\end{array}$ & $\begin{array}{l}\text { Türk ruh birliğinin sağlanması için müssterek } \\
\text { dili parçalamaya yönelik bir sürü kabile } \\
\text { lehçeleri ve mahalli alfabelerle karşı İsmail } \\
\text { Gaspıralının "dilde, fikirde, işte birlik" } \\
\text { umdesini kabul etmek gerekir. Türk ruhu } \\
\text { için Türkçeden başka bir nahvi (söz dizimi) } \\
\text { düşünmemek gerekir. }\end{array}$ & $\begin{array}{l}\text { Dil İnkılabına Nahiv } \\
\text { De Karıştırılabilir Mi? }\end{array}$ & 1 & 6 & 296-315 \\
\hline Osman Turan & $\begin{array}{l}\text { Araştırma- } \\
\text { Inceleme }\end{array}$ & $\begin{array}{l}\text { Dede Korkut hikayeerinin en bilinenlerinden } \\
\text { Bey Böyrek 'in ispir rivayetine yer verilmiştir. }\end{array}$ & $\begin{array}{l}\text { Bey Böyrek Hikayesinin } \\
\text { Yeni Rivayetleri, I. }\end{array}$ & 2 & 8 & $126-137$ \\
\hline Osman Turan & $\begin{array}{l}\text { Araştırma- } \\
\text { Inceleme }\end{array}$ & $\begin{array}{l}\text { Dede Korkut hikayelerinin en bilinenlerinden } \\
\text { Bey Böyrek 'in ispir rivayetine yer verilmiştir. }\end{array}$ & $\begin{array}{l}\text { Bey Böyrek Hikayesinin } \\
\text { Yeni Rivayetleri, II. }\end{array}$ & 2 & 9 & $174-178$ \\
\hline Paul Achard & $\begin{array}{l}\text { Araştırma- } \\
\text { Inceleme }\end{array}$ & $\begin{array}{l}\text { Türk tarihine ilişkin bilgiler yer almaktadır. } \\
\text { Makale Türkçeye çevrilmiştir. Siyasetle ilgili } \\
\text { bölümlerinin çıkarıldığı ifade edilmiştir. }\end{array}$ & Türkiye & 2 & 10 & $226-228$ \\
\hline Peyami Safa & Eleştiri & $\begin{array}{l}\text { Hilmi Ziya Ülken'in İnsan mecmuasında } \\
\text { yayınlanan Türk Milliyetçiliği hakkındaki bir } \\
\text { makalesi eleştirilmektedir. }\end{array}$ & $\begin{array}{l}\text { Türk Milliyetçiliği ve } \\
\text { Felsefe Sistemleri }\end{array}$ & 1 & 4 & $270-272$ \\
\hline $\begin{array}{l}\text { Raşit Saffet } \\
\text { Atabinen }\end{array}$ & $\begin{array}{l}\text { Araştırma- } \\
\text { Inceleme }\end{array}$ & $\begin{array}{l}\text { İskandinav tarihi içerisinde Türk-Fin } \\
\text { kültürüne ilişkin çeşitli argümanlar } \\
\text { sunulmaktadır. }\end{array}$ & $\begin{array}{l}\text { İsveç ve Norveçte } \\
\text { Türk-Fin Kanı İzleri }\end{array}$ & 3 & 13 & $394-400$ \\
\hline $\begin{array}{l}\text { Refik Ahmet } \\
\text { Sevengil }\end{array}$ & Biyografi & $\begin{array}{l}\text { Saray mızıkası mensupları askeri rütbe } \\
\text { sahibidir. Tiyatrocu Halil'de burada kolağası } \\
\text { rütbesine kadar yükselmiş biridir. (1863-1938) }\end{array}$ & $\begin{array}{l}\text { En Eski Türk } \\
\text { Aktörlerden Kolağası } \\
\text { Halil }\end{array}$ & 1 & 1 & $67-70$ \\
\hline $\begin{array}{l}\text { Refik Ahmet } \\
\text { Sevengil }\end{array}$ & $\begin{array}{l}\text { Araştırma- } \\
\text { Inceleme }\end{array}$ & $\begin{array}{l}\text { Şeytan Rober, Cezalda, Polyoto, Lüsi } \\
\text { de Lamermur ve HocavNaum'un opera } \\
\text { oyunlariyla ilgili bilgi veriliyor }\end{array}$ & $\begin{array}{l}\text { İstanbul'da Oynanmış } \\
\text { ve Basılmış Operalar }\end{array}$ & 2 & 7 & $1-5$ \\
\hline $\begin{array}{l}\text { Refik Ahmet } \\
\text { Sevengil }\end{array}$ & Biyografi & $\begin{array}{l}\text { İstanbul'a turneler tertip eden heyetler içinde } \\
\text { yer alan Madam Ristori hakkında bilgiler } \\
\text { veriliyor. }\end{array}$ & $\begin{array}{l}\text { XIX Uncu Astrda } \\
\text { İstanbul'da Bir İtalyan } \\
\text { Artisti }\end{array}$ & 2 & 8 & 99-101 \\
\hline Rıza Ruşen Yücer & $\begin{array}{l}\text { Araştırma- } \\
\text { Inceleme }\end{array}$ & $\begin{array}{l}16 \text { 'ıncı asrın sonlarından itibaren tutulan } \\
\text { sicillerin önemini belirten bir yazıdır. }\end{array}$ & $\begin{array}{l}\text { Bursa ve Mahkeme } \\
\text { Sicilleri }\end{array}$ & 2 & 9 & $279-281$ \\
\hline Riza Yalgin & $\begin{array}{l}\text { Araştırma- } \\
\text { Inceleme }\end{array}$ & $\begin{array}{l}\text { Adana Müzesinde Ramazanoğlu } \\
\text { Kütüphanesinin } 2745 \text { numarasında kayıtlı } \\
\text { Türkçe bir şecere kitabı anlatılmaktadır. }\end{array}$ & $\begin{array}{l}\text { El Yazması: } 215 \\
\text { Yaşında Bir Kitap, } \\
\text { Güzel Bir Türk Şeceresi }\end{array}$ & 2 & 11 & $286-292$ \\
\hline $\begin{array}{l}\text { Sadettin Nüzhet } \\
\text { Ergun }\end{array}$ & Eleştiri & $\begin{array}{l}\text { H.Sadettin Aral'ın Türk musikisi kimindir? } \\
\text { Başliklı makale sersisine dair değerlendirmeler } \\
\text { içermektedir. }\end{array}$ & $\begin{array}{l}\text { Türk Musikisi Tarihine } \\
\text { Dair Notlar }\end{array}$ & 3 & $\begin{array}{l}14- \\
15\end{array}$ & $473-483$ \\
\hline $\begin{array}{l}\text { Selim Nüzhet } \\
\text { Gerçek }\end{array}$ & $\begin{array}{l}\text { Araştırma- } \\
\text { Inceleme }\end{array}$ & $\begin{array}{l}\text { İstanbul Halkevinde verilmiş bir } \\
\text { konferanstır. Karagöz oyunu hakkındadır. }\end{array}$ & "Hayalin" Hakikati & 2 & 8 & $92-98$ \\
\hline $\begin{array}{l}\text { Stilyanos } \\
\text { Stasinopulos }\end{array}$ & $\begin{array}{l}\text { Araştırma- } \\
\text { Inceleme }\end{array}$ & $\begin{array}{l}1939 \text { Erzincan deprem üzerine deprem } \\
\text { bölgeleri ve hareketleri üzerine bilgiler } \\
\text { verilmektedir. }\end{array}$ & Anadolu Zelzeleleri, I. & 2 & 11 & $314-316$ \\
\hline
\end{tabular}




\begin{tabular}{|c|c|c|c|c|c|c|}
\hline $\begin{array}{l}\text { Stilyanos } \\
\text { Stasinopulos }\end{array}$ & $\begin{array}{l}\text { Araştırma- } \\
\text { Inceleme }\end{array}$ & $\begin{array}{l}1939 \text { Erzincan deprem üzerine deprem } \\
\text { bölgeleri ve hareketleri üzerine bilgiler } \\
\text { verilmektedir. }\end{array}$ & Anadolu Zelzeleleri, II. & 3 & $\begin{array}{l}14- \\
15\end{array}$ & $441-444$ \\
\hline $\begin{array}{l}\text { Şükufe Nihal } \\
\text { Başar }\end{array}$ & Biyografi & $\begin{array}{l}\text { Ahmet Ağaoğlu'nun vefatı münasebetiyle } \\
\text { kaleme alınmıştır. Üstadın masasında açık } \\
\text { kalın kitaplar Türklük için hazırladığı ikinci } \\
\text { etüdün kaynaklarıymış. }\end{array}$ & Ahmet Ağaoğlu & 1 & 3 & $189-193$ \\
\hline$T \ddot{U R K L U ̈ K}$ & Editoryal & $\begin{array}{l}\text { Mahmut Ragıp Kösemihal'in Nazan } \\
\text { Danişmed'in Haçlı Türk Bayrakları } \\
\text { Meselesine yaptığı eleştirilere cevap } \\
\text { mahiyetindedir. }\end{array}$ & Cevabin Cevabı & 1 & 3 & $240-243$ \\
\hline$T \ddot{U R K L U ̈ K}$ & Editoryal & $11^{\prime}$ inci sayının takdimi mahiyetindedir. & $\begin{array}{l}\text { Tanzimat'in Yüzüncü } \\
\text { Yıl Dönümü }\end{array}$ & 1 & 4 & 249 \\
\hline$T \ddot{U R K L U ̈ K}$ & Editoryal & $\begin{array}{l}\text { Eğinli Sait Paşa Hatıratının takdimi } \\
\text { mahiyetindedir. }\end{array}$ & $\begin{array}{l}\text { İlk Meşrutiyet } \\
\text { Devrinin En Mühim } \\
\text { Vesikası: Eğinli Sait } \\
\text { Paşa Hatıratı }\end{array}$ & 1 & 4 & 262 \\
\hline TÜRKLÜK & Editoryal & $\begin{array}{l}\text { Mahmut Ragıp Kösemihal'in Nazan } \\
\text { Danişmed'in Haçlı Türk Bayrakları } \\
\text { Meselesine yaptığı eleştirilere cevap } \\
\text { mahiyetinde yazılan editoryal yazıya ilave } \\
\text { açıklama mahiyetindedir. }\end{array}$ & Tavzihin Tavzihi & 1 & 4 & $328-329$ \\
\hline TÜRKLÜK & Editoryal & $\begin{array}{l}26 \text { Ağustos } 1071 \text { Malazgirt Zaferinden } \\
\text { bahsederek Oğuz Türklerinin en büyük } \\
\text { bayramı olarak kutlamaktadır. }\end{array}$ & $\begin{array}{l}\text { Türkiye Devletinin } 868 \\
\text { inci Yıl Dönümü }\end{array}$ & 1 & 5 & 337 \\
\hline TÜRKLÜK & Editoryal & $\begin{array}{l}\text { Derginin başmuharriri(başyazarı) İsmail } \\
\text { Hami Danişmend tarafından kaleme } \\
\text { alındığı düşünülmektedir. Derginin Türklük, } \\
\text { Türkçülük meselelerine bakış açısını millet ve } \\
\text { milliyet kavramları üzerinden açılamaktadır. } \\
\text { Derginin milliyetçi kültü̈r mecmuası sıfatıyla } \\
\text { yayın hayatında olacağı anlatılmaktadır }\end{array}$ & Mesleğimiz & 1 & 1 & $1-4$ \\
\hline$T \ddot{U R K L U ̈ K}$ & Editoryal & $\begin{array}{l}\text { "Gazup Bir Şair" isimli Abdülhak Hamid } \\
\text { şiirinden önce verilmiştir. }\end{array}$ & $\begin{array}{l}\text { Abdülhak Hamid'in } \\
\text { Nesep Şeceresi }\end{array}$ & 1 & 2 & 99 \\
\hline$T \ddot{U R K L U ̈ K}$ & Editoryal & $\begin{array}{l}\text { Eski Türklerde matem rengi, mobilyacılık, } \\
\text { Saatte } 10 \text { kelimeden fazla konuşması yasak } \\
\text { olan askerler, kadınlarda boynuz takma } \\
\text { âdeti gibi unsurlar küçük pasajlar halinde } \\
\text { aktarılmıştır. }\end{array}$ & $\begin{array}{l}\text { Eski Türk Kültürünün } \\
\text { Unutulmuş Noktaları }\end{array}$ & 2 & 7 & $60-62$ \\
\hline$T \ddot{U R K L U ̈ K}$ & Editoryal & $\begin{array}{l}\text { Yusuf Ziya Demircinin Anadolu Köylerinin } \\
\text { Türküleri, Bürhaneddin Matbaası, İstanbul, } \\
1938 \text { kitabının tanıtımıdır. }\end{array}$ & $\begin{array}{l}\text { Anadolu Köylerinin } \\
\text { Türküleri } \\
\text { (Bibliyografya) }\end{array}$ & 2 & 9 & 208 \\
\hline$T \ddot{U R K L U ̈ K}$ & Editoryal & $\begin{array}{l}\text { Zeki Ömer Defne'nin Bu Memleket Böyle } \\
\text { Ağlar isimli şiirinin takdimi mahiyetindedir. }\end{array}$ & $\begin{array}{l}\text { Türk Edebiyat } \\
\text { Tarihinin } \\
\text { Unutmıyacağı Bir Şiir }\end{array}$ & 2 & 11 & 296 \\
\hline TÜRKLÜK & Editoryal & $\begin{array}{l}\text { J.H Mordtman'ın İslam Ansiklopedisinde yer } \\
\text { alan "Danişmendiyye maddesi aynen tercüme } \\
\text { ve neşredilmiştir. Takdimi mahiyetindedir. }\end{array}$ & Melik Gazi Türbesi & 2 & 12 & 357 \\
\hline TÜRKLÜK & Editoryal & $\begin{array}{l}\text { Ali Kami Akyüz'ün kardeşi hakkında yazdığı } \\
\text { yazıya takdim mahiyetindedir. }\end{array}$ & $\begin{array}{l}\text { Ölümünün Kırkıncı } \\
\text { Yıldönümü } \\
\text { Münasebetiyle: İsmail } \\
\text { Safa }\end{array}$ & 3 & 13 & 389 \\
\hline
\end{tabular}




\begin{tabular}{|c|c|c|c|c|c|c|}
\hline V.Y. Muçooğlu & Tercüme & $\begin{array}{l}\text { Nikoforos Vriyennios vakayinamesinin Türkler } \\
\text { hakkındaki bölümleri yayınlanmaktadır. } \\
\text { Veriyennios } 1062 \text { doğumludur. }\end{array}$ & $\begin{array}{l}\text { Vriyennios } \\
\text { Vakayinamesi }\end{array}$ & 2 & 11 & $317-319$ \\
\hline V.Y. Muçooğlu & Tercüme & $\begin{array}{l}\text { Nikoforos Vriyennios vakayinamesinin Türkler } \\
\text { hakkındaki bölümleri yayınlanmaktadır. } \\
\text { Veriyennios } 1062 \text { doğumludur. }\end{array}$ & $\begin{array}{l}\text { Vriyennios } \\
\text { Vakayinamesi }\end{array}$ & 2 & 12 & $367-368$ \\
\hline V.Y. Muçooğlu & Tercüme & $\begin{array}{l}\text { Nikoforos Vriyennios vakayinamesinin Türkler } \\
\text { hakkındaki bölümleri yayınlanmaktadır. } \\
\text { Veriyennios } 1062 \text { doğumludur. }\end{array}$ & $\begin{array}{l}\text { Vriyennios } \\
\text { Vakayinamesi }\end{array}$ & 3 & 13 & $415-417$ \\
\hline $\begin{array}{l}\text { Yusuf Ziya } \\
\text { Demirci }\end{array}$ & $\begin{array}{l}\text { Araştırma- } \\
\text { Inceleme }\end{array}$ & $\begin{array}{l}\text { Yörüklerin hayatı ve kültürüyle ilgili bilgiler } \\
\text { yer alıyor. } 95 \text { yaşındaki bir yörü̈̆̈̈ü fotoğrafı } \\
\text { var. }\end{array}$ & Yörükler & 2 & 10 & 223-225 \\
\hline Zeki Ömer Defne & Şiir & $\begin{array}{l}\text { Güncel şiir (normalde tarihi olmayan şiirleri } \\
\text { yayınlamiyorlar) }\end{array}$ & $\begin{array}{l}\text { Bu Memleket Böyle } \\
\text { Ağlar (Şiir) }\end{array}$ & 2 & 11 & 296-297 \\
\hline
\end{tabular}

\section{Türklük Mecmuasındaki Örnek Metinler Üzerine Değerlendirmeler}

"Milliyetçi Kültür Mecmuası" olması hasebiyle dergide yer alan konuların neredeyse tamamı Türk kültürünü oluşturan unsurlarla doğrudan ilgili hususlardan müteşekkildir. Daha ilk sayısında ünlü Türkologlardan A.Zayonçkovski'nin "Marzuban-nâme"20 başlığını taşıyan Anadolu Türk edebiyatının on dördüncü yüzyılda yazılmış eski bir belgesine istinat ettiği yazısını yayınlamıştır. "Acemce bir masal mecmuasının eski Anadolu lehçesine yapılmış ilk tercümesi" olan bu eserle on dördüncü asır Anadolu Türk saraylarının kültürel durumu ve faaliyetleri hakkında malumat verilmektedir.

Derginin ilginç ve önemli iddiaları muhtevi yazılarından biri hiç şüphesiz Nazan Danişmend imzasını taşıyan Anadolu Türk beyliklerine ait bayraklardaki haçlarla ilgili makaledir. Bilindiği üzere tarihten beri Türklerde bayrak, arma ve damgaya özel önem atfedilmiştir. Çin, Fars ve Türk kaynaklarında da bu durum anlaşılmaktadır. Hükümdarlık alametleri arasında sayılan diğer unsurlarla birlikte bayrağın da özel bir hususiyet taşıdığı bilinmektedir. Bununla birlikte Anadolu'nun Türk-İslamlaşması sürecinde özellikle de Anadolu Türk beylikleri döneminde Türk bayrakları ile ilgili kesin ve net bilgilerin bulunamadığını belirten Nazan Danişmend, makalesinde bir İspanyol vesikasına dayanarak bu dönemin bayrakları ile ilgili ilginç bazı bilgileri paylaşmıştır. 1305 'te doğan bir papaz, İspanya'dan kalkıp Çin'e kadar bütün coğrafyayı dolaşarak yazdığı seyahatnamede gittiği memleketlerde gördüğü bütün bayrakları, renkleri ve şekilleriyle tespit etmiştir. İspanya'da bu eserden yalnızca üç nüsha kalmış ve bunları 1877'de Don Marcos Jiménes de la Espada isimli bir İspanyol müellif karş1laştırarak neşretmiştir. Bu eser Sir Clements Markham tarafından "Book of the Knowledge" ismiyle İngilizceye tercüme edilerek Londra'da basılmıştır. Makaleye mehaz olarak ele alınan tercüme de budur. Her ne kadar papazın bu eseri kaleme alırken bizzat seyahat etmeden kaleme aldığına dair iddialar bulunsa da eserde gözle görülmeden anlatılmasına imkan olmayan birçok hususun bulunduğu anlaşılmaktadır. 14. yüzyılın ilk yarısına ait bu eserde Anadolu'da yer alan Türk Beyliklerinin bayraklarındaki haç sembolleri ayrıntılı olarak izah edilmiştir. Seyyah papazın gördügü yerlerdeki bayrakları renkli bir şekilde göstererek açıkladığı eserinde Tekeoğulları, Osmanoğulları, Karamanoğulları ve Eretna Beyliklerine ait bayraklardaki haç işaretlerine dikkat çekilmiştir. Nazan Danişmend'e göre Müslüman-Türk bayraklarında haç şekilleri bulunmasının dört ihtimale dayanabileceği değerlendirilmiştir: " 1 . Komşu Hıristiyan bayraklarının taklit ve tesiri, 2. Hiristiyan kültürünün alametleri ile etraftaki ecnebi ve bilhassa Bizans Hıristiyanları üzerinde cazip tesir icrası, 3. Anadolu Türk Beyliklerinde Hıristiyan tebaa bulunduğu için laik bir zihniyet tesiri, 4. Bu saliplerin dinî olmayıp tamamıla milli işaretler olmak ihtimali". Danişmend, dördüncü ihtimali daha kuvvetli görerek buna delil olarak da Kaşgarlı Mahmud'un Divanında Eymür boyunun damgasının da bir salip şeklinde tespit edilmiş olmasını göstermektedir. "Manası her ne olursa olsun, herhalde biz salibi Türk âleminde

20 A.Zayonçkovski, "Anadolu Türk Edebiyatının XIVüncü Asra Ait Mühim Bir Vesikası: MarzubanNâme”, Türklük, C.1, S.1, Nisan 1939, s. 5-12 
Müslümanlıktan evvel olduğu gibi sonra da buluyoruz" diyen yazar, bütün bu delillere göre bir tahminde bulunduğunu vurgulamıștır. ${ }^{21} \mathrm{Bu}$ yazıdan mülhem Nazan Danișmend'e ithaf edilerek Hüseyin Namık Orkun tarafından Türklerdeki armalar ve kartal arması üzerinde değerlendirmelerin yapıldığı bir makale neşredilmiştir. Osmanlı armasının yabancı bir şirketten alındığı ve devlete mâl edilmeye çalışıldığı, Türkiye Cumhuriyeti'nin Selçuklu gibi arma meselesine ehemmiyet verdiğinin belirtildiği makalede Selçuklu armasındaki çift başlı kartala dikkat çekilmiştir. ${ }^{22}$

Türklük Mecmuasında İsmail Hami Danişmend'in 1rk meselelerine dair tespit ve değerlendirmeleri de önemli yer tutmaktadır. Tarihin en eski devirlerinden beri insanları meşgul eden ırkın tayini ve insanlığın muayyen bir takım gruplara ayrılması meselelerini farklı ilimler zaviyesinden ele alan Danişmend, ırkları çeşitli özelliklerine göre tasnif ederek izah etmiștir. Ona göre "Irk mefhumunda vatan birliği şartı yoktur; ırk, antropolojik ve zoolojik bir mefhumdur; fakat milliyeti yani tâlî ırk mefhumunda ilk aranılan şey vatan yani coğrafi müessir esasıdır. Çünkü herhangi bir cemaate ırk̂̉ şahsiyetinin yanında millî bir şahsiyet de verip onu bir milliyet haline getiren ilk âmil tabiat, yani muayyen bir memlekettir. Bu âmil o kadar kuvvetlidir ki Fransız kavmi gibi muhtelif urklardan mürekkep bir halitaya bile nihayet millî bir şahsiyet vermiştir. Fakat hiç şüphesiz ki en kuvvetli milletler, ırkî şahsiyetle millî şahsiyeti cemeden cemiyetlerdir." ${ }^{23}$ Nazan Danişmend'in bu makalesine yönelik olarak Mahmut Ragıp Kösemihal, yine Türklük dergisinde cevap mahiyetinde bir yazı neşretmiştir. Makalede Müslüman Selçuklulardan önce Bizans idaresindeki Anadolu ve İstanbul'a bazı “Ortodoks Türkler”in geldiği ve bunların hem kültür birliği sayesinde Selçuklu hakimiyetini kolaylaştırdığ 1 hem de onların İslam'a geçişte uysallık göstereceği iddia edilmiștir. "Hıristiyan Türklerin bu akide farklarını Mikail, Yakup gibi isimlerle Islam Türklerden gizleyebilmiş, gizli ayinlere çekilmiş olmaları bile mümkündü. Bahsedilen haçlı bayrakları bu devrin son hatıraları" olarak değerlendirilmiștir. ${ }^{24}$ Kösemihal'in bu cevabî yazısına Türklük dergisi de 15 maddeden müteşekkil bir yazıyla cevap vermiştir. Bu yazıda Selçuklulardan önce "Ortodoks Türkler"in Anadolu’ya iltica ettiğinin delilleri tenkit edilmiş ve Müslümanlık döneminde de "gizli din" taşımış gibi gösterilmesinin dayanaksız olduğuna değinilmiştir. ${ }^{25}$

Cumhuriyet döneminin önemli yazım usullerinden biri olan bunun gibi cevabî yazılar ve tenkitlere, Türklük'ün çeşitli sayılarında yer verilmiştir. Hüseyin Namık Orkun, bir cevabî yazısında o günlerde genç bir yazar olan Orhan Şaik Gökyay’ı Ülkü Mecmuasındaki eleştiri yazısına yönelik alaylı ve küçümseyici bir dille uzun uzun eleştirmiștir. ${ }^{26}$ Hüseyin Namık Orkun gibi M.Şakir Ülkütaşır da Dede Korkud'un naşiri olan Gökyay'ı bu eseriyle ilgili olarak özellikle de yazım hatalarına dikkat çeken eleştiri yazıları kaleme almıştır. ${ }^{27}$ Orkun, Oluş mecmuasında Abdülkadir İnan'ın da konuya müdahil olmasıyla birlikte İnan'a hitaben Gökyay'ı eleştiren kısa bir yazı daha kaleme almıştır. ${ }^{28}$ Benzer șekilde Ismail Hami Danişmend de ırk ve Türklerin kökeni hakkındaki makale ve kitabıyla ilgili 6 sayfalık bir eleştiri yazısı kaleme alan genç yazarı "küçük münekkidim" hitaplarıyla küçümseyici bir tarzdaki yazı ile eleştiren cevabî bir yazı yazmıştır. ${ }^{29}$

21 Nazan Danimend, “On Dördüncü Asra Ait Bir İspanyol Vesikasına Göre: Anadolu Türk Beyliklerinin Haçlı Bayrakları", Türklük, C.1, S.1, Nisan 1939, s. 12-22

22 Hüseyin Namık Orkun, "Eski Türklerde Kartal Arması", Türklük, C.2, S.7, Birinciteşrin (Ekim) 1939, s.29-34

23 İsmail Hami Danişmend, "Eski Şark ve Yeni Garp Telâkkilerine Göre Irk Nedir?”, Türklük, C.1, S.1, Nisan 1939, s. 39-57

24 Mahmut Ragıp Kösemihal, "Haçlı Türk Bayrakları Meselesi”, Türklük, C.1, S.3, 1 Haziran 1939, s. 237240

25 Türklük, "Cevabın Cevabı”, Türklük, C.1, S.3,1 Haziran 1939, s. 240-242

26 Hüseyin Namık Orkun, “Üçüncü Ders”, Türklük, C.1, S.4, 1 Temmuz 1939, s.273-282

27 M. Şakir Ülkütaşır, "Dede Korkud'un O.Şaik Gökyay Neşri Üzerine Tenkidî Notlar”, Türklük, C.1, S. 4, 1 Temmuz 1939, s. 330-336; M. Şakir Ülkütaşır, “Dede Korkud’un Orhan Şaik Gökyay Neşri Üzerine Tenkidî Notlar II”, Türklük, C.1, S. 6, 1 Eylül 1939, s. 491-496

28 Hüseyin Namık Orkun, "Bir İzah”, Türklük, C.1, S.5, Ağustos 1939, s.416

29 İsmail Hami Danişmend, "Bir Zihniye Hastalığı”, Türklük, C.1, S.4, 1 Temmuz 1939, s. 283-295 
Derginin ilk sayısından son sayısına kadar devam eden yazılardan biri Hüseyin Sadettin Arel imzasını taşıyan "Türk Musikisi Kimindir?" başlıklı makale dizisidir. Türk musikisini diğer kültürlerin musikileri ile karşılaştırılarak hazırlanan makalede önemli bilgiler verilmiştir. Delillerini sunarak İran ve Bizans musikilerindeki Türk etkisi üzerine değerlendirmelerde bulunan Arel, Türk hâkimiyetinde bulunan coğrafyalarda yerli musikilerin Türk etkisi ile şekillendiğini misalleriyle ortaya koymuş ve Türk musikisinin başka bir milletten geldiği iddialarına cevap vermiştir. ${ }^{30}$ Türk idaresi dönemi "her ne taksimatlı olursa olsun eski musiki sistemini yıkıp yok etmiş ve yerine kendi 24 taksimatl sistemini koymuştur. Bugün İran'daki musiki işte bu yirmi dört taksimatlı Türk musikisidir." 31 İran musikisinden herhangi ciddi bir etkinin olmadığını belirten Arel, Arap musikisinin de Türk musikisine ciddi bir etkisi ve katkısı olmadığını belirtmiștir. ${ }^{32}$ Hatta Arap musikisinin makamları, usulleri, sazları ve 1stılahları gibi oldukça fazla unsuru Türk musikisinden aldığına değinmiştir. ${ }^{33}$ Bununla birlikte Türk musikisi hakkında yabancı muharrirlerin görüşlerine değinen ve bu görüşlerdeki tutarsızlıkları dile getiren Danişmend, Fransız müsteşrik Jules Rounet'nin düşüncelerini incelemiştir. Rounet'nin Türk, Arap, Acem, Ermeni ve Yahudi gibi birçok milletin ortak musiki kullandığ musikiye ilk sahip olan be onu böyle memleket memleket dolaştırıp önüne gelene dağıtan millet hangisidir?" sorusunu sorarak Türk musikisine dikkati çekmiştir. ${ }^{34}$ Makale dizisinde okuyucu mektuplarına da değinen Arel, Arap musikisi ve Mısır'daki musiki kültürünün Türk kaynakları hakkında bilgiler vermiştir. ${ }^{35}$ Buraya kadar İranlılardan veya Araplardan Türklere musiki geçip geçmediğini izah eden Arel, bundan sonraki makalesinde eski Yunan musikisini ele alarak bunun Türk musikisinden de Batı musikisinden de fazlaca farklılığı olduğundan bahsetmiştir. ${ }^{36}$ Makamlarını da inceledikten sonra Yunan musikisinden Türk musikisine herhangi bir alıntı yapılıp yapılmadığını değerlendirmiştir. Delillendirerek ortaya koyduğu düşüncelerinde Türk musikisi ile Yunan musikisi arasındaki yabancılığın okuyucuların dahi anlayabilecek teknik bilgiye sahip olduğunu ifade etmiştir. ${ }^{37}$ Acemlerden, Araplardan ve Yunanlardan musiki almamış olduğumuzu yaptığ 1 tetkiklerle izah eden Hüseyin Sadettin Arel, Bizans musikisini ele alarak Türk musikisinin kaynağı hakkında bilgilendirmeye devam etmiştir. ${ }^{38}$ Konuyla ilgili yazdığı son makalesinde yine Bizans musikisi hakkında genişçe bilgi verdikten sonra karşılaştırmalar yapmıștır. Bu arada "millî musikimizin resmen konservatuarlara kabul edip mümkün olduğu kadar çok ve mümkün olduğu kadar çabuk bestekârlar yetiştirilmesi" gerektiği üzerinde durarak makale dizisini şu ifadelerle sonlandırmıştır: "Müstakbel bestekârlarımızdan umduğum hizmetlerin en küçüğ̈̈, bugün majörde de minörde de diğer makamlarımızda da hep inilti taklidi haline gelmiş olan yeni üslubumuzu ağlayıp ağlamaktan halas edecek bir reçete bulmaktır dersem inanınız." 39 Hüseyin Sadettin Arel'in yazı dizisi doğu ve batı musikisi arasında sıkışmış Türk musikisi anlayışlarına yönelik dönemin Türk Tarih Tezi'ne benzer bir yaklaşımla "Türk Musiki Tezi” ortaya koyma gayreti ve girişimi

30 Hüseyin Sadettin Arel, “Türk Musikisi Kimindir? I” Türklük, C.1, S.1, Nisan 1939, s. 57-66

31 Hüseyin Sadettin Arel, "Türk Musikisi Kimindir? II” Türklük, C.1, S.2, 1 Mayıs 1939, s. 160

32 Hüseyin Sadettin Arel, “Türk Musikisi Kimindir? III” Türklük, C.1, S.3, 1 Haziran 1939, s. 227-236

33 Hüseyin Sadettin Arel, “Türk Musikisi Kimindir? IV” Türklük, C.1, S.4, 1 Temmuz 1939, s. 316-327

34 Hüseyin Sadettin Arel, "Türk Musikisi Kimindir? V” Türklük, C.1, S.5, Ağustos 1939, s. 383-397

35 Hüseyin Sadettin Arel, "Türk Musikisi Kimindir? VI” Türklük, C.1, S.6, 1 Eylül 1939, s. 452-469

36 Hüseyin Sadettin Arel, "Türk Musikisi Kimindir? VII” Türklük, C.2, S.7, Birinciteşrin (Ekim) 1939,s. 45-59

37 Hüseyin Sadettin Arel, “Türk Musikisi Kimindir? VIII” Türklük, C.2, S.8, İkinciteşrin (Kasım) 1939, s. 113-125; Hüseyin Sadettin Arel, “Türk Musikisi Kimindir? IX” Türklük, C.2, S.9, Birincikanun (Aralık) 1939, s. 162-173; Hüseyin Sadettin Arel, "Türk Musikisi Kimindir? X” Türklük, C.2, S.10, İkincikanun (Ocak) 1940, s. 241-255; Hüseyin Sadettin Arel, "Türk Musikisi Kimindir? XI” Türklük, C.2, S.11, 1 Şubat 1940, s. 298-313

38 Hüseyin Sadettin Arel, "Türk Musikisi Kimindir? XII” Türklük, C.2, S.12, 31 Mart 1940, s. 340-356; Hüseyin Sadettin Arel, “Türk Musikisi Kimindir? XIII” Türklük, C.3, S.13, 30 Nisan 1940, s. 401-413

39 Hüseyin Sadettin Arel, "Türk Musikisi Kimindir? XIV” Türklük, C.3, S.14-15, İkinciteşrin (Kasım) 1940, s. $445-472$ 
biçiminde değerlendirilebilir.

Derginin ilginç yazılarından biri de İsmail Hami Danişmend imzalı on yedinci yüzyıldaki bir "Türk ırkçısı" olarak nitelendirilen Vânî Mehmed Efendi hakkındaki makaledir. Makaleye göre Arap müfessirleri ve şarihleri içinde ırkçılık ve milliyetçilik taassubuyla her firsatta Türk ırkının aleyhine fikir beyan edenlerin uydurma efsaneleri, Arap medreselerinden Türk medreselerine de sirayet etmiştir. "Eski İstanbul'un ulema sınıfı içinde Türk olmayan unsurlara mensup zümrenin mühim yekûn teşkil etmesi tabii bu vaziyetin takarrür ve devamında ihmal edilmeyecek bir âmil sayılabilir." Osmanlı medrese tarihine bakıldığında bu duruma karşı milliyet adına "isyan etmiş" tek kişinin Vânî Mehmed Efendi'nin olduğu iddia edilmiştir. Arap müfessirlerinin Ye'cuc ve Me'cuc bahsini Türklere bağlamasına mukabil, Mehmed Efendi bilakis bunlara karșı demir ve bakırdan bir set yaptıran Zülkarneyn'in Türk olduğunu belirtmiștir. Uzun izahlardan sonra İsmail Hami Danişmend, Vânî Mehmed Efendi'nin “Türk milliyetinin XVII'nci asırda yetişen bu büyük mübeşşiri müphem bir Turancı değil, vâzıh bir Türkçü ve onun Türkçülügünün çok sıkı bir ırkçılık esasına dayandığını" ifade etmiștir. Danişmend'in makalesi şu ifadelerle sona ermiştir: "Türk milliyetinin büyük şshidi Vânî Mehmed Efendi merhumu İslam vahdetine ihanetle itham edenler, hakikatte işte bu Arap zihniyetiyle Türklükleri uyuşmus veyahut trk itibariyle Türk olmadıları için Arap kültürüne uymuş insanlard. Vânî'nin bilhassa böyle bir devirde yetişsmiş olduğunu düşünürsek ne koyu bir karanlıktan doğmuş ne büyük bir nur olduğunu daha iyi anlamış oluruz."

28 Aralık 1937'de Beyoğlu Halkevi’nde “Türk Güzelliği” hakkında tartışmalı bir konferans veren Nazan Danişmend, bu metni radyoda özetlemiş ve konu büyük bir ilgi uyandırmıştır. Eski Türklerin vesikalarla ispat edilen güzel tipi ile ilgili konferansını yazıya döken Danişmend, bunu Türklük dergisinde yayınlamıştır. Derginin ilginç makalelerinden biri olan bu yazıda özellikle de yabancı kaynaklarda geçen şekliyle Türk tipi ve güzelliği incelenerek "Muhtelif devirlerle muhtelif memleketlerde parlak medeniyetleriyle askerî ve siyasî teşkilatçılıktaki kuvvet ve kudretleri sayesinde eski dünyaya boydan boya hâkim olan büyük Türk ırkının ruhî ve manevi güzelliği kadar maddi güzelliğiyle de bütün dünya ırklarını gölgede bıraktığı, yabancıların ve hatta Türk düşmanı yabanciların hep birbirini teyit eden şehadetleriyle sabit" olduğu belirtilmiştir. ${ }^{41}$

Türkçülük tarihinde önemli bir yer edinmiş olan Ahmed Ağaoğlu'nun Türk dili ve lisan meseleleri üzerine kısa bir makalesi de Türklük'te yayınlanmıştır. ${ }^{42}$ Aynı sayıda Mayıs ayında hayatını kaybeden Ağaoğlu hakkında Şükufe Nihal imzasıyla bir vefa yazısı kaleme alınmıștı. ${ }^{43}$ Halkbilimi ve kültürü sahasında da makalelere yer veren Türklük’te çıkan bir makalede Azeri Türkleri arasında yaygın olan batıl inançlar incelenerek Anadolu Türklüğündeki benzerliklerine değinilmiştir. ${ }^{44}$ Ahmed Caferoğlu'nun bu makalesinden sonra dergide İstanbul'la ilgili batıl inançların kaleme alındığı bir makale yayınlanmıştır. Bu makalede hamilelik, doğum, çocuk sahibi olma, nikah, düğün, kızların kısmeti, ölüm, yol, tırnak kesme, süpürge, elbise, ayakkabı, boyun uzaması, zayıflık, şişmanlık, bazı hayvanlar, rüyalar, adak venazar değme gibi konular ele alınmıştıı. ${ }^{45}$ Dergide yayınlanan ve ilginç sonuçları olan bir makale de Osman Gazi'nin soyu ve kimliği ile ilgili bir makaledir. Buna göre Osman Gazi'nin babası Ertuğrul, bir gemici ve bilhassa korsandır. "Fakat yaşadığı umumi anarşi devrinde siyasi emellerle hareket edip bilhassa Bizans arazisinden kendine pay çıkarmak isteyen siyasi bir korsandır. Âdî bir korsan değildir." "Ertuğrul'un babasının kim olduğu meçhuldür. Süleymanşah ibn Kayaalp ibn Kızılboğa soyu uydurmadır." "Osman ’in kendisi de babası gibi büyük deniz seferleri yapmış kahraman bir Türk gemicisidir ve babasından vâris olduğu denizciliği kendisi de oğlu Orhan'a kuvvetli bir donanma ile miras bırakmıştır." Kısaca

40 İsmail Hami Danişmend, "Arap ve Türk Kültürlerinin Mücadele Tarihinden: On Yedinci Asırda Bir Türk Irkçısı”, Türklük, C.1, S. 2, 1 Mayıs 1939, s.122-142

41 Nazan Danişmend, "Tarih ve Edebiyatta Türk Güzelliği”, Türklük, C.1, S.3, 1 Haziran 1939, s.169-184

42 Ahmet Ağaoğlu, "Lisaniyat", Türklük, C.1, S.3, 1 Haziran 1939, s. 185-188

43 Şükufe Nihal, "Ahmet Ağaoğlu”, Türklük, C.1, S.3, 1 Haziran 1939, s. 189-193

44 Ahmed Caferoğlu, “Azeri Türk Hayatında Bâtıl İtikatlar”, Türklük, C.1, S.3, 1 Haziran 1939, s.194-206

45 Cahide Başol, “İstanbul'da Bazı Bâtıl İtikatlar”, Türklük, C.2, S.9, Birincikanun (Aralık) 1939, s. 179-185 
makaleye göre Osmanlı Devleti karada değil, denizde doğmuş demektir. ${ }^{46}$ İsmail Hami Danişmend, Osmanoğulları'nın kökeni ile ilgili zaman zaman basında çıkan iddialara da dergisi Türklük'te cevap vermiştir. Osmanlıların Türklüğünü kaynaklara dayanarak ispat eden Danişmend, "Tatarlık" ve "Mongolluk" konularına da değinmiştir." Peyami Safa'ya ithaf ettiği bu konudaki üçüncü yazısında da Osmanoğulları'nın "Rumluğu” meselesini ele alarak bunun mümkün olamayacağını dile getirmiştir. ${ }^{48}$ Benzer şekilde Osmanlıların denizciliği ve soyu ile ilgili görüşlerini tenkit eden basında çıkan yazılara karşı da İsmail Hami Danişmend, uzun bir yazı ile cevap vermiştir. ${ }^{49}$

Mecmuada yayınlanan önemli yazı dizilerinden biri hiç şüphesiz II.Abdülhamit döneminin önemli tarihi şahsiyetlerinden Eğinli Sait Paşa'nın hatıratını konu edinen yazılardır. Dördüncü sayıdan başlayan hatırat, on üçüncü sayıya kadar on bölüm halinde devam etmiştir. 13'üncü sayıda yer alan son yazının altında "devamı var" şeklinde bir ibare olmasına rağmen tek cilt halinde yayınlanan 14-15. sayıda hatırat yer almamıştır. Yazı dizisinin öncesinde dedesi Eğinli Sait Paşa ile ilgili üç fotoğrafın da yer aldığı bir biyografi ${ }^{50}$ hazırlayan Nazan Danişmend, dönemin en önemli vesikasını dergide yayınlayarak I. Meşrutiyet döneminin daha vazıh bir şekilde anlaşılmasına katkı sağlamıştır. Sultan Abdülhamit' in ilk Mabeyn Müşiri ve Bahriye Nazırı olan Eğinli Sait Paşa padişahın "ilk cülûs ettiği gün Mabeyndeki vazifesine başlamış ve her günkü hadisatı her akşam ruzname tarzında yazarak milli tarihimizin o devri için en mühim vesikayl vücuda getirmiştir. Üslubu o zamana göre çok sadedir; adeta konuşur gibi yazıyor; yalnız o devrin âdet ve zihniyetince bilhassa padişahtan bahsederken hürmetkâr bir ifade ile "Zat-l Şahane”, "Şevketmeab" vesaire gibi bir takım unvanlar kullanıyor... Sait Paşa'nın bu resmi unvanları mütemadiyen kullanmasında o zamanki zihniyetten başka bir âmil daha var: Yazdiğı defterlerin ele geçmek ihtimali. Bu ihtimali daima hesap eden paşa, bilhassa Abdülhamit'in gözünden düşüp valilikle saraydan ve Istanbul'dan uzaklaştırıldıktan sonra çok mufassal olan hatıratını ihtisar etmiş ve işte bu muhtasar nüshayı saklayıp tehlikeli saydığı mufassal nüshayı refikasının ısrarı üzerine ocağa atıp yakmış! Bugün elde kalan işte bu muhtasar nüshadır ve bunda padişahtan bahsederken pek ihtiyatkâr bir ifade kullanması her halde pek tabiidir... Sait Paşa'nın hatıratı, kendi el yazısıyla yedi büyük defter tutuyor; bunlar muhteviyat itibariyle üç kısma ayrllabilir: Birinci kısım merhumun Mabeyn Müşirliğinde bulunduğu devre, ikinci kısım Abdülhamit' in hışmına uğrayarak valiliklerle Anadolu ve Suriye'ye teb’id edildiği zamana ve üçüncü kısım da kalp hastalığından dolayı İstanbul'a avdetinden vefatı tarihine kadar geçen senelere aittir. Son devir tarihimizi alakadar eden siyasi hadiseler hep birinci ve üçüncü kisımlardadır." 51 Türklük mecmuasında bu yedi defterden birincisi ve yedincisi neşredilmiştir.

Türk kültürünün bütün unsurlarını sayfalarına taşımaya gayret eden Türklük, yedinci sayıdan itibaren kültürümüzün unutulmuş ve ilginç noktalarını neșretmeye bașlamıștır. Bu bölümde bütün dünyada matem renginin siyah olmasına karşın eski Türklerde bilakis beyaz olduğuna dikkat çekilmiştir. Anadolu'da hüküm sürmüş beyliklerden birinin (Eretna Devleti) sultanı olan Eretna Bey (Erdana) çok iri yarı, dev gibi bir adammış, onu taşıyacak at olmadığı için "daima sığıra binip gezdiğinden" bahsedilmiştir. Çin'de tesadüf edilen biniciliğin bu şekline 14. yüzyılda

46 İsmail Hami Danişmend, “Osman Gazi’nin Nesep ve Hüviyeti”, Türklük, C.1, S.3, 1 Haziran 1939, s. 207223

47 İsmail Hami Danişmend, “Osmanoğullarına İsnad Edilen Sahte Milliyetler”, Türklük, C.1, S.5, Ağustos 1939, s.367-382

48 İsmail Hami Danişmend, “Osmanoğullarına İsnad Edilen Sahte Milliyetler”, Türklük, C.1, S.6, 1 Eylül 1939, s. 425-437; İsmail Hami Danişmend, “Osmanoğullarına İsnad Edilen Sahte Milliyetler”, Türklük, C.2, S.7, Birinciteşrin (Ekim) 1939, s.10-19

49 İsmail Hami Danişmend, "Osman Gazi’nin Nesep ve Hüviyeti Hakkındaki Tenkide Cevap”, Türklük, C.1, S.6, 1 Eylül 1939, s. 477-489

50 Nazan Danişmend, "Türk Demokrasi Tarihinin Unutulmuş Simalarından Eğinli Sait Paşa”, Türklük, C.1, S.4, 1 Temmuz 1939, s. 249-261

51 “ỉlk Meşrutiyet Devrinin En Mühim Vesikası: Eğinli Sait Paşa Hâtıratı", Türklük, C.1, S. 4 , 1 Temmuz 1939, s. 262; Eğinli Sait Paşa’nın hatıratı Türklük mecmuasının 4., 5., 6., 7., 8., 9., 10., 11., 12. ve 13. sayılarında neşredilmiştir. 
Anadolu'da da tesadüf edilmiştir. Osmanlı'nın ilk dönemlerinde askerlerin on kelimeden fazla söz söylemelerinin yasak olduğu, Dördüncü Murat devrinde İstanbul'da bir hayvanat bahçesinin bulunduğu, Çin kaynaklarına dayanarak Türk kadınlarında boynuz takma geleneği bulunduğu ifade edilmiştir. ${ }^{52}$ Bunun yanında Türklük mecmuasında Türk tarihine özel vesikalar, yazmalar, eserler, yazıtlar da orijinali ve değerlendirmesi ile birlikte yayınlanmıştır.

Türklük mecmuasındaki yazılara bakıldığında dönemin resmi tarih ve dil söylemine uygun ve destekleyecek mahiyette yayınlar yapıldığı anlaşılmaktadır. Bu yazılardan birinde Sümer ismi ${ }^{53}$ diğerinde de Sümer $1 \mathrm{rk1}^{54}$ ele alınmıştır. Buna göre "Sümer milliyeti, Orta Asya'dan gelmiş muhtelif Türk dalgalarının bir halitası" olarak değerlendirilmiştir.

Mecmuada Anadolu Türk tarihinin önemli kaynakları, Türk tarihinin önemli şahsiyetlerinin biyografileri ve Türk kültürünün unsurları farklı sayılarda ele alınmış ve değerlendirilmiştir.

\section{Sonuç}

“Milliyetçi Kültür Mecmuası” nitelemesiyle marufTürklük Mecmuası, tarihçi ve Türk kültürü araştırmacısı ve mütefekkir İsmail Hami Danişmend'in çıkardığı bir dergidir. Nisan 1939-Kasım 1940 arasında 15 sayı olarak çıkmıştır. Dönemin şartları göz önüne alındığında kaliteli bir baskıyla aylık olarak okuyucunun karşısına çıkmıştır. Derginin "Mesleğimiz" başlıklı ilk yazısından son yazılarına kadar Türk ırkı ve Türk kültürü alanında makale ve çeviri gibi araştırmalar yayınlanmıştır. Dergi güncel siyasi meselelerden ziyade tarih ve kültürle yoğrulmuş sayılar neşretmiştir. Özellikle Türk dili, Türk edebiyatı, Türk ırkı, Türk sanatı, Türk tarihi ve Türk kültürü üzerinde durmuştur.

Yazar kadrosu incelendiğinde dönemin münevverlerinden birçok insana rastlandığı gibi müteveffa tarihî şahsiyetlerin eserleri de yayımlanmıştır. Günümüzde milliyetçiliğiyle bilinen mütefekkirlerin yanında yabancı uyruklu Türkolog ve bilim insanlarının görüş ve düşüncelerine de yer verilmiştir. Türk musikisi, edebiyat, tiyatro, dil, kültür, eski kitabe çevirileri, folklor, etnoğrafya, eski Türklerin bayrak ve armaları, şiir, biyografi, kitap ve dergi tanıtımları, eski tarihi vesikalar gibi çeşitli içerikte orijinal ve tarihî kıymeti haiz yazılara yer veren dergi, resmi tarih ve dil söylemine uygun ve destekleyecek bir yayın politikası takip etmiştir. Bu noktada Hüseyin Sadettin Arel'in uzun yazı dizisinde doğu ve batı musikisi arasında sıkıșmış Türk musikisi anlayışlarına yönelik dönemin Türk Tarih Tezi'ne benzer bir yaklaşımla “Türk Musiki Tezi” ortaya koyma gayreti dikkati çekmektedir. Mecmua ayrıca Anadolu Türk tarihinin önemli kaynakları, Türk tarihinin önemli şahsiyetlerinin biyografileri ve Türk kültürünün unsurlarına özel önem atfederek yayınlamıştır. "Irkçı, dilci, kültürcü ve vatancı" kimliği ile dikkati çeken Türklük, Türklüğe hizmet ederek ismiyle müsemma bir yayın çizgisi takip etmiştir.

\section{Kaynakça}

“Eski Türk Kültürünün Unutulmuş Noktaları”, Türklük, C.2, S.7, Birinciteşrin (Ekim) 1939 “İlk Meşrutiyet Devrinin En Mühim Vesikası: Eğinli Sait Paşa Hâtıratı”, Türklük, C.1, S. 4, 1 Temmuz 1939

"Mesleğimiz", Türklük, S.1, Nisan 1939

Achard, Paul, "Türkiye”, Türklük, S.10, İkincikanun (Ocak) 1940

Ağaoğlu, Ahmet, “Lisaniyat”, Türklük, C.1, S.3, 1 Haziran 1939

Alkan, Mustafa - Gül, Adnan, "İsmail Hami Danişmend (1889-1967)”, Türk Yurdu, Ocak 2011, Y1l 100, S. 281 
Arel, Hüseyin Sadettin, “Türk Musikisi Kimindir? I” Türklük, C.1, S.1, Nisan 1939

Arel, Hüseyin Sadettin, “Türk Musikisi Kimindir? II” Türklük, C.1, S.2, 1 Mayıs 1939

Arel, Hüseyin Sadettin, “Türk Musikisi Kimindir? III” Türklük, C.1, S.3, 1 Haziran 1939

Arel, Hüseyin Sadettin, “Türk Musikisi Kimindir? IV” Türklük, C.1, S.4, 1 Temmuz 1939

Arel, Hüseyin Sadettin, "Türk Musikisi Kimindir? IX" Türklük, C.2, S.9, Birincikanun (Aralık) 1939

Arel, Hüseyin Sadettin, “Türk Musikisi Kimindir? V” Türklük, C.1, S.5, Ağustos 1939

Arel, Hüseyin Sadettin, “Türk Musikisi Kimindir? VI” Türklük, C.1, S.6, 1 Eylül 1939

Arel, Hüseyin Sadettin, "Türk Musikisi Kimindir? VII” Türklük, C.2, S.7, Birinciteşrin (Ekim) 1939

Arel, Hüseyin Sadettin, "Türk Musikisi Kimindir? VIII” Türklük, C.2, S.8, İkinciteşrin (Kasım) 1939

Arel, Hüseyin Sadettin, "Türk Musikisi Kimindir? X” Türklük, C.2, S.10, İkincikanun (Ocak) 1940

Arel, Hüseyin Sadettin, "Türk Musikisi Kimindir? XI” Türklük, C.2, S.11, 1 Şubat 1940

Arel, Hüseyin Sadettin, “Türk Musikisi Kimindir? XII” Türklük, C.2, S.12, 31 Mart 1940

Arel, Hüseyin Sadettin, “Türk Musikisi Kimindir? XIII” Türklük, C.3, S.13, 30 Nisan 1940

Arel, Hüseyin Sadettin, "Türk Musikisi Kimindir? XIV" Türklük, C.3, S.14-15, İkinciteşrin (Kasim) 1940

Ata, Ferudun, İsmail Hami Danişmend'in “Irk" Üzerine Bazı Tespitleri”, Tarihin Peşinde, S. 9, Y11, 2013

Başol, Cahide, “İstanbul'da Bazı Bâtıl İtikatlar”, Türklük, C.2, S.9, Birincikanun (Aralık) 1939

Caferoğlu, Ahmed, “Azeri Türk Hayatında Bâtıl İtikatlar”, Türklük, C.1, S.3, 1 Haziran 1939

Cevizliler, Erkan, "Sivas Kongresi Divan-1 Riyâset Kâtibi İsmail Hami (Dânişmend)", Atatürk Dergisi, C:3, Şubat 2010

Danimend, Nazan, “On Dördüncü Asra Ait Bir İspanyol Vesikasına Göre: Anadolu Türk Beyliklerinin Haçlı Bayrakları", Türklük, C.1, S.1, Nisan 1939

Danişmed, Nazan, “Tarih ve Edebiyatta: Türk Güzelliği”, Türklük, S.3, 1 Haziran 1939

Danişmend, İsmail Hami, “Arap ve Türk Kültürlerinin Mücadele Tarihinden: On Yedinci Asırda Bir Türk Irkçısı”, Türklük, C.1, S. 2, 1 Mayıs 1939

Danişmend, İsmail Hami, “Bir Zihniye Hastalığı”, Türklük, C.1, S.4, 1 Temmuz 1939

Danişmend, İsmail Hami, “Eski Şark ve Yeni Garp Telakkilerine Göre: Irk Nedir?”, Türklük, S.1, Nisan 1939

Danişmend, İsmail Hami, “Eski Şark ve Yeni Garp Telâkkilerine Göre Irk Nedir?”, Türklük, C.1, S.1, Nisan 1939

Danişmend, İsmail Hami, “Osman Gazi’nin Nesep ve Hüviyeti Hakkındaki Tenkide Cevap”, Türklük, C.1, S.6, 1 Eylül 1939

Danişmend, İsmail Hami, “Osman Gazi’nin Nesep ve Hüviyeti”, Türklük, C.1, S.3, 1 Haziran 1939 Danişmend, İsmail Hami, “Osmanlıların Aslı Meselesi: I, Osman Gazi’nin Nesep ve Hüviyeti”, Türklük, S.3, 1 Haziran 1939

Danişmend, İsmail Hami, “Osmanoğullarına İsnad Edilen Sahte Milliyetler”, Türklük, C.1, S.5, Ağustos 1939

Danişmend, İsmail Hami, “Osmanoğullarına İsnad Edilen Sahte Milliyetler”, Türklük, C.1, S.6, 1 
Eylül 1939

Danişmend, İsmail Hami, “Osmanoğullarına İsnad Edilen Sahte Milliyetler”, Türklük, C.2, S.7, Birinciteşrin (Ekim) 1939

Danişmend, İsmail Hami, “Sümerlilerin Irkı”, Türklük, C.2, S.10, İkincikanun (Ocak) 1940

Danişmend, İsmail Hami, "Sümerlilerin İsmi”, Türklük, C.2, S.9, Birincikanun (Aralık) 1939

Danişmend, Nazan, “Tarih ve Edebiyatta Türk Güzelliği”, Türklük, C.1, S.3

Danişmend, Nazan, "Türk Demokrasi Tarihinin Unutulmuş Simalarından Eğinli Sait Paşa", Türklük, C.1, S.4, 1 Temmuz 1939

Eckhardt, Par Alexandre, "La Légende de l'origine Troyenne des Turcs", Türklük, C.2, S. 12, 31 Mart 1940

Gerçek, Selim Nüzhet, "Hayalin Hakikati”, Türklük, S.8, İkinciteşrin (Kasım)1939

Kösemihal, Mahmut Ragıp, "Haçlı Türk Bayrakları Meselesi”, Türklük, C.1, S.3

Küçük, Cevdet, "Danişmend, İsmail Hami”, TDV İslam Ansiklopedisi, C.8, İstanbul, 1993

Nihal, Şükufe, “Ahmet Ağaoğlu”, Türklük, C.1, S.3, 1 Haziran 1939

Orkun, Hüseyin Namık, "Bir İzah”, Türklük, C.1, S.5, Ağustos 1939

Orkun, Hüseyin Namık, “Eski Türklerde Kartal Arması”, Türklük, C.2, S.7, Birinciteşrin(Ekim)1939

Orkun, Hüseyin Namık, “Üçüncü Ders”, Türklük, C.1, S.4, 1 Temmuz 1939

Özcan, Ömer, "Milliyetçi Kültür Dergisi Türklük”, Türk Yurdu, S. 213, Mayıs 2005

Sanal, Haydar, “Arel Hüseyin Sadeddin”, TDV İslam Ansiklopedisi, C.3, İstanbul, 1991

Türklük, “Cevabın Cevabı”, Türklük, C.1, S.3, 1 Haziran 1939

Ülkütaşır, M. Şakir, "Dede Korkud'un O.Şaik Gökyay Neşri Üzerine Tenkidî Notlar”, Türklük, C.1, S. 4, 1 Temmuz 1939

Ülkütaşır, M. Şakir, "Dede Korkud'un Orhan Şaik Gökyay Neşri Üzerine Tenkidî Notlar II”, Türklük, C.1, S. 6, 1 Eylül 1939

Zayonçkovski, A. , "Anadolu Türk Edebiyatının XIVüncü Asra Ait Mühim Bir Vesikası: MarzubanNâme”, Türklük, C.1, S.1, Nisan 1939

\section{(Footnotes)}

1 Sayfa numarası 326 olarak yazılması gerekirken sehven 325 yazılmıştır. Sonraki ciltlerdeki sayfalar da buna göre numaralandırılmıştır. 